
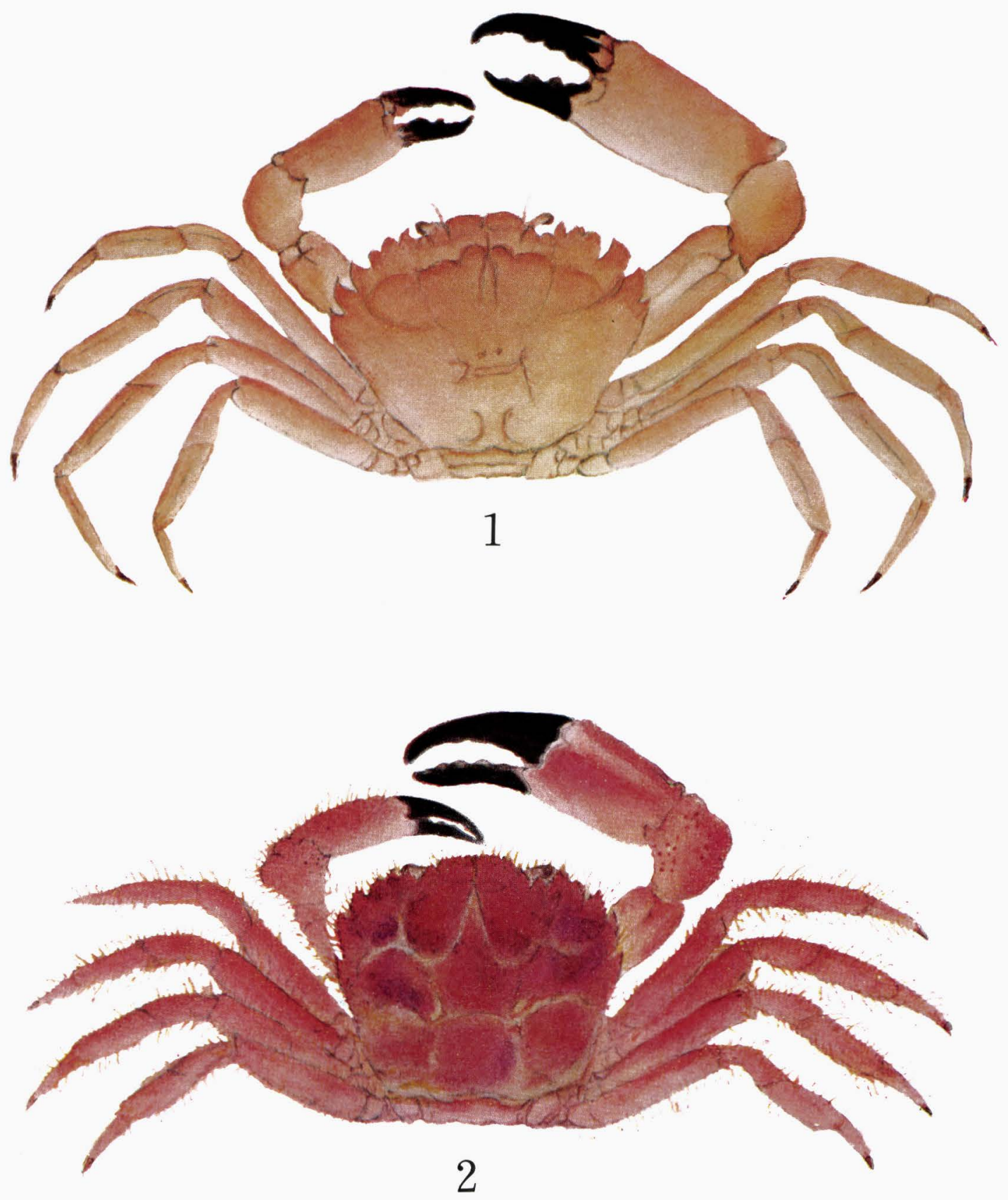

Fig. 1. Boiroisia major, (SAKAI, 1978).

Fig. 2. Intesius pilosus, Guinot \& B. Richer de Forges 1981. 
Researches on Crustacea, No. 12 (1983)

Carcinological Society of Japan

Odawara Carcinological Museum

Azabu-Juban 3-11, Minatoku, Tokyo

(Issued-Aug. 30, 1983)

\title{
DESCRIPTION OF NEW GENERA AND SPECIES OF JAPANESE CRABS, TOGETHER WITH SYSTEMATICALLY AND BIOGEOGRAPHICALLY INTERESTING SPECIES. (I)
}

\author{
With 1 Frontispiece and 8 Plates \\ by \\ Tune SAKAI \\ (Carcinological Society of Japan.)
}

In these several years, a large number of Japanese crabs have been gathered, some of which were collected by myself and others by earnest local collectors of Japan. Before writing these species, the author must thanks for these collectors, and specially gratitudes for Dr. T. ODAwARA, the Director of the Odawara Carcinological Museum, for his financial help to establish this report.

The names of such crabs are as follows:

Fam. Dromiidae De HAAN, 1933.

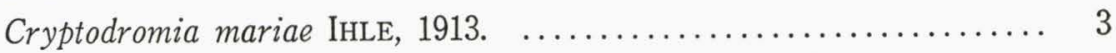

Petalomera actidens New Species. ........................ 3

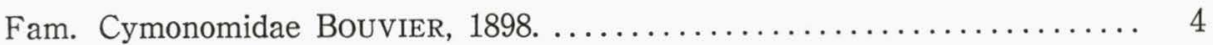

Cymonomus sagamiensis New Species $\ldots \ldots \ldots \ldots \ldots \ldots \ldots \ldots \ldots . \ldots . \ldots 4$

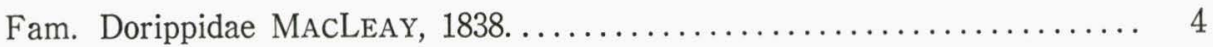

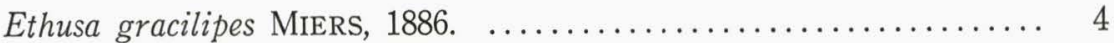

Ethusa serenei New Species. ........................ 5

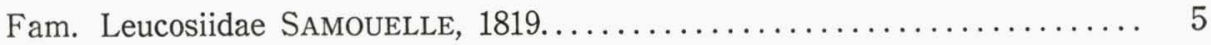

Praebebalia longidactyla YoKoya, 1933. ................. 5

Praebebalia kumanoensis New Species. ...................... 5

Philyra iriomotensis New Species. ...................... 6

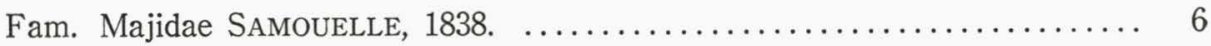

Paraentomonyx New Genus. ............................. 6

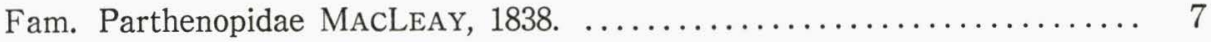

Parthenope (Platylambrus) praedator (DE MAN, 1906)........... 7

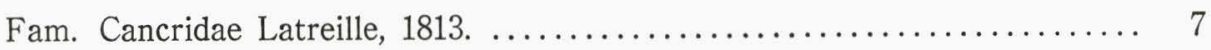

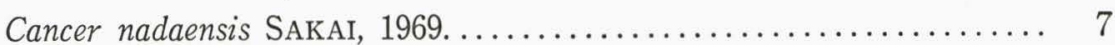

On phantasmic Cancer balssi SaKaI, $1972 . \ldots \ldots \ldots \ldots \ldots \ldots \ldots \ldots . \ldots \ldots$

Fam. Portunidae Rafinesque, $1815 \ldots \ldots \ldots \ldots \ldots \ldots \ldots \ldots \ldots \ldots \ldots \ldots \ldots \ldots \ldots \ldots$ 
Caphyra minabensis New Species. . ....................... 8

Charybdis (Charybdis) anisodon DE HAAN, 1833. .............. 9

Fam. Xanthidae Macleay, 1838. ............................. 9

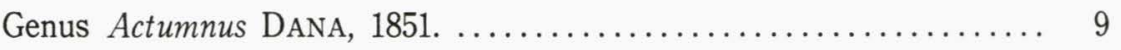

Actumnus dorsipes (STIMPSON, 1858).................... 10

Species related to the genus Actumnus............. 10

On Actumnus elegans DE MAN, 1887. ................... 10

On Platypodia digitalis Rathbun, 1907. ................... 11

On Pilumnus marginatus Stimpson, 1858. ................. 11

On Actumnus similis Takeda and Miyake, 1969. ............. 12

Analysis of the genus Actaea De HaAn, $1833 \ldots \ldots \ldots \ldots, 12$

Lobiactaea New Genus. ................................ 12

Lobiactaea lobipes (ODHNER, 1925)....................... 12

Odhneria New Genus................................... 13

Odhneria acutidens New Genus and Species. ................ 13

Odhneria echina (ALCOCK 1898, new combination). .............. 14

Genus Platypodia BeLL, 1835. ......................... 14

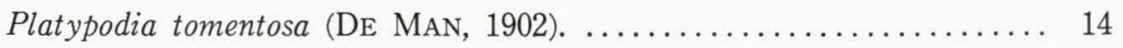

Platypodia semigranosa (HELler, 1861). ................... 15

Genus Serenius Guinot 1976 ............................ 15

Serenius gemmula (DANA, 1852)......................... 15

Nanocassiope granulipes (SAKAI, 1939). . . . . . . . . . . . . . . 15

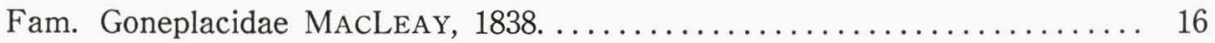

Beuroisia major (SAKAI, 1978). .......................... 16

Intesius pilosus GuINot and B. Richer DE Forges, 1981. ........ 16

Fam. Pinnotheridae DE HAAn, 1933. .......................... 16

Sakaina japonica SERÈnE, 1964......................... 16

Fam. Ocypodidae Rafinesque, 1815. .......................... 17

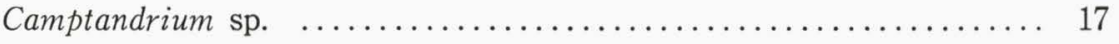

Deiratonotus tondensis New Species, 1983. ................. 17

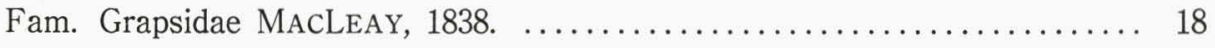

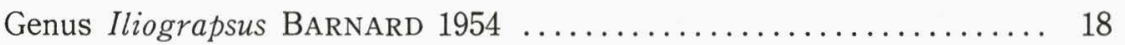

Iliograpsus nodulosus New Species. .................... 18

Metopograpsus latifrons (WHite, 1848). ................. 19

Neoeriocheir New Genus, 1983. ........................ 19

Neoeriocheir leptognathus (RATHBUn, 1914). ................... 20 
Fam. Dromiidae De HaAN, 1833.

Cryptodromia mariae IHLE, 1913.

(Pl. V, Fig. A)

Cryptodromia mariae IHLE, 1913, Siboga Expeditie, I Dromiacea, Monographie xxxix b, p. 38, pl. 1 , figs. 5,6 .

Material examined:

1\}, 2 우 우, Kumano-Nada, Wakayama Prefecture, coll. by E. IIsHibA, 1975.

A small species, without any tubercles nor spines. The carapace is smooth and the front is widely divergent, the median rostral tooth is very small, almost invisible from above. The antero-lateral teeth are two behind the outer orbital one, and are separated by two shallow fissures. The merus of the chelipeds is armed with two tubercles near the distal end. The propodus and dactylus of the first and second pairs of ambulatory legs are very slender and long. This is the first record of occurrence of this species in Japan.

Measurements: Length of carapace $11.5 \mathrm{~mm}$, width of same also $11.5 \mathrm{~mm}$.

Distribution: Kumano-Nada, Mie Prefecture and west of New Guinea.

\section{Petalomera acutidens New Species.}

(Pl. I, Fig. 2.)

Material examined:

3소, 1우, Wagu, mouth of Ise Bay. Coll. by N. Yamashita, 1980.

This species is closely related to Petalomera nodosa SAKAI, 1936, but it differes in the different form of the antero-lateral borders, which are connected ventrally with the corner of the buccal cavity. This border is armed with five or six sharp teeth instead of the obtuse, granulated nodules of $P$. nodosa. The front is strongly projected anteriorly, divided into two broad lobes. On the dorsal surface of carapace, the gastric region is armed with a pair of tall granulated nodules on each side. The $3 \mathrm{M}^{*}$ and $4 \mathrm{M}^{*}$ are armed with a low nodules. The branchial region is also armed with a low process, covered with granules. In the fourth abdominal tergum, there is a pair of nodules like those of $P$. nodosa.

As in $P$. nodosa, the chelipeds and ambulatory legs are granulated. The distal end of the merus and propodus are armed with two small nodules. The third and fourth ambulatory legs are very thin.

Measurements : Length of carapace $21.5 \mathrm{~mm}$, width of same $24.5 \mathrm{~mm}$.

Distribution: Known only from Wagu, mouth of Ise Bay.

\footnotetext{
* The letters indicating areolae of carapace in this report are after J. DANA 1852.
} 
Fam. Cymonomidae Bouvier, 1898.

Cymonomus sagamiensis New Species

(Pl. VIII, Fig. A)

not Cymonomus andamanicus Alcock, 1905, p. 568, PI. XIII, fig. 1-1a-1b; Illus. Invest. Crust P1. 79, fig. 2.

Cymonomus quadratus andamanucus, SAKaI, 1976, p. 37, pl. 8, fig. 1.

Material examined:

1우, dried specimen, Kumano-Nada, Mie Prefecture. coll. by H. IIsнiBA, 1976.

A female specimen, which is dried and fragmentary, but it is probably identical with the specimen, described by me in 1976, in the name of Cymonomus quadratus andamanidus AlCOck, which is different species by having the carapaece raunded quadangular. The carapace is regurlarly quadrate and the median and lateral frontal teeth are very short. The lateral anterior corner of the carapace is angled and obscurely bidentate. The species is closely related to the Cymonomus delli* GRIFFIN, 1976, from the deep sea of Australia, but the carapace of that species is less strongly tuberculated and the anterior two pairs of the ambulatorey legs are not at all granulated nor spinulated, compaired with those of the present species. Cymonomus umitakae TAKEDA, 1981 is also a distinct species by having the stronger rostral teeth.

Distribution; Sagami Bay, Kumano-Nada.

Fam. Dorippidae Macleay, 1838.

Ethusa gracilipes Miers, 1886.

(Pl. IV, Fig. A; Fig. E)

Ethusa (Ethusina) gracilipes Miers, 1886, p. 332, pl. 29, figs. 1a-c; Alcock 1894, c. 177.

Not Ethusa (Ethusina) gracilipes var. robusta Miers, 1886, p. 333, pl. 29, figs. 2a-b=Ethusina robusta Miens.

Not Aethusina gracilipes, FAxson, $1895=$ Ethusina robusta.

Not Ethusina gracilipes, IHLE, 1916, p. 147, fig. 147, fig. $77=$ Ethusina desciens (after SERENE and LohavaniJaya, 1973).

Not Ethusina gracilipes, Rathbun, 1937, p. 94, pl. 30, fig. 4; pl. 31, fig. 3=Ethusina sp. Not Ethusina robusta, as Serene and Lohavanijaya identified.

Not Ethusa gracilipes, Serène and Lohavanijaya, 1973, p. 35, figs. 56-59, pl. IV, C-D=Ethusa serenei New Species.

Material examined:

1今, Suruga Bay, 2300-2780 Meters deep (deepest for the crabs of Japan), coll. by Dr. Takeshi Umezu, Tokai-ku Fish. Exper. Station, Tokyo.

The true Ethusa gracilipes is rare, deep sea crab. The carapace is rather flat and its human-faced sculpture is rather obscure. The front is composed of two pairs of

\footnotetext{
* Deepwater Decapod Crustacea from Easterm Australia: Brachyuran Crabs. by D. J. GRIFfin and
} Diante E. Brown: The Australian Museum, Sydney. 
spines divided by a deep median fissure and the lateral two are again divided into two by a shallow lateral fissure. The outer orbital spines are slender, but their tips do not reach the tips of the four frontal spines.

The chelipeds and two anterior pairs of ambulatory legs are very slender like those of Latreillia or Latreillopsis. In true Ethusa gracilipes, the merus of the anterior legs is very slender, about 13 times as long as broad. In SERÈnE and LoHAVANIJAyA's figure, the legs are thick and short, the merus being about six times as long as broad. SERÈNE and LoHAVANiJaya's specimen seems to be a distinct species. Moreover, the male anterior pleopod of Ethus gracilipes is thick and straight, while that of SERÈNE and LOHAVANIJAYA's specimen, it is thin and bent outwards, and a few setae are seen near its tip.

Measurements: Length of carapace $10 \mathrm{~mm}$, width of same $9.5 \mathrm{~mm}$.

Distribution: The true localities for this species are only off Philippines and Suruga Bay, Japan.

\section{Ethusa serenei New Species.}

Ethusa gracilipes SerÈne and Lohavanijaya, 1973, p. 35, text-figs. 56-59, pl. IV, C-D.

Among various localities enumerated for Ethusa gracilipes by previous authors, many are due to error, only MiERs's original locality and my present one are correct. A new species, Ethusa serenei is established herewith from the China Sea.

Fam. Leucosiidae SAmouelle, 1819.

Praebebalia longidactyla YoKoYA, 1933.

(P1. IV, 2)

Praebebalia longidactyla YoKoy A, 1933, p. 125, text-fig. 39; SAKAI, 1966, p. 77, text-fig. 39 (YoKOYA's figure).

Material examined:

1우, Kumano Nada, Mie Prefecture, coll. by H. IIsHiba, 1976.

A small and dried specimen, but its life colour is remained. The carapace is longitudinally and irregularly striped in yellowish brown.

The chelipeds are also irregularly banded by the same color.

Measurements: Length of carapace $5.8 \mathrm{~mm}$, width of same $5.0 \mathrm{~mm}$.

Distribution: Japan only, Suruga Bay, Kumano-Nada, Bungo Strait and Goto Islands.

Praebebalia kumanoensis New Species.

(Pl. IV, Fig. C) 
Material examined:

1 우, holotype, Kumano-Nada, Mie Prsfecture, from the wastes of the trawl-net, coll. by $\mathrm{H}$. IISHIBA.

A small and dried specimen, no its coloration is remained. The carapace is posteriorly broadened; the frontal and posterior borders are almost straight. The dorsal surface is covered with tiny granules, which are a little larger in anterior and frontal regions, very small and thicker in posterior and postero-lateral sides. The intestinal region is convex and thickly covered with tiny granules.

The chelipeds are very long, more than twice the length of carapace.

Measurements: Length of carapace $5.5 \mathrm{~mm}$, width of same $5.0 \mathrm{~mm}$.

Distribution: Known only from Kumano-Nada, Mie Prefecture.

Philyra iriomotensis New Species.

(Pl. V, Figs. C, $\mathrm{C}_{1}-\mathrm{C}_{3}$ )

Material examined :

$1 \hat{\delta}, 1$ 우, one male of which is designated to a holotype; Kuira River, Iriomote, Okinawa. Coll. by H. Yoshikawa, Kagoshima Univ., Oct. 1980.

1§, same locality, same methode, by Mr. Kazuhito OsADA, 1981.

A small species, living on the mud flat of the mangrove of the Kuira River of Iriomote Island. The carapace is rhomboidal in shape, longer than broad, and its front straight and medially depressed. The hepatic facet is very narrow. The margin of carapace is tuberculated and its posterior border almost straight, marked with three processes, one median and the others on either lateral side. In the dorsal surface of the carapace, the gastric area is granulated in rohmboidal shape, the lateral and posterior surfaces are slso granulated, otherwise the remain surface is non-granular.

The male abdomen is narrow and long, its male anterior pleopod is, as figured on Pl. V, C, $\mathrm{C}_{1 \sim 2}$, an elongate process is seen near the distal end.

Measurements: Length of carapace $5.0 \mathrm{~mm}$, width of same $5.5 \mathrm{~mm}$.

Distribution: Known only from Iriomote, Okinawa.

Fam. Majidae Samouelle, 1819.

Paraentomonyx New Genus.

(Pl. I, Fig. 1; Pl. V, Figs. D, $D_{1}$ )

Type species: Entomonyx depressus SAKAI, 1974.

Entomonyx depressus SaKaI, 1976, p. 272, text-fig. 149.

The new genus Paraentomonyx differs from Entomonyx in the form of rostral horns, which are broad and depressed in the basal half, and their tips rounded and inwardly directed. The upper orbital eaves are very broad and its proximal end is marked with 
a projection. The postorbital tooth is also very broad and its outer free edge is marked with two denticles. Between the two spines, the intercalated spine is very short and its tip does not reach the orbit. The hepatic border is also depressed, and is armed with two processes. The anterolateral border behind the hepatic spines is armed with four teeth, of which the first one small, and the last one very large and deviated onto the dorsal branchial surface. The posterior border is armed with a pair of processes, while in Entomonyx as well as in Chlorinoides, which are related to the present genus, the posterior end is marked with a single median spine only.

The male anterior pleopod is bent outward at tip, without spine, different from the two other genera. The new genera is represented by a single species from Kii Minabe and Ise Bay.

Measurements: Length of carapace, without rostral and posterior spines, $24.5 \mathrm{~mm}$, width of same $19 \mathrm{~mm}$.

Fam. Parthenopidae Miers, 1879.

Parthenope (Platylambrus) praedator (DE MAN, 1906)

(Pl. I, Fig. 3)

Oncodolambrus praedator De MAN, 1906, Ann. Mag. Nat. Hist. ser. 7, vol. 17, p. 400; 1907, p. 389 , pl. 31, figs. 1-3.

Lambrus (Oncodolambrus) praedator, SAKAI, 1965, p. 91.

Parthenope (Platylambrus) praedator, SAKAI, 1976, p. 272, text-fig. 149.

Material examined:

1§, Kumano-Nada, Mie Prefecture, coll. by H. IsshiBa from the wastes of the trawling net.

The type of this species is preserved in the British Museum (Natural History), which was reexamined and figured by the present writer in 1960. The present specimen is the second one of this species, obtained from Kumano-Nada, Mie Prefecture. A photo of the entire animal is reproduced hierwith. Although this is the normal specimen, however, it looks like abnormal, as if its branchial regions are swollen by infected by the Bopyrid.

Measurements : Length of carapace $11 \mathrm{~mm}$, width of same $16 \mathrm{~mm}$, cheliped $29 \mathrm{~mm}$.

Distribution: Japan, Kumano-Nada and Inland Sea.

Fam. Cancridae LAtreille, 1803.

Genus Cancer Linné, 1758.

The genus Cancer is the oldest and fundamental genus estabsished by Carl v. LinNE, in 1758. In Japan, this genus comprises 6 species in all, viz.,

Cancer gibbosulus (DE HAAN, 1835) 
C. japonicus ORTMANN, 1893

C. amphioetus RAthBUN, 1898

C. tumifrons YoKOYA, 1933

C. nadaensis SAKAI, 1969

C. sakaii TAKEDA and MIYAKE, 1972.

In my recent paper, $C$. luzonensis $\mathrm{n}$. $\mathrm{sp}$. is in the press, which is near $C$. nadaensis, but the sculptures of the carapace are more deep (in Proc. Biolo. Soc. Washington, vol. 97.)

Cancer nadaensis SAKAI, 1969.

(Pl. VI, Fig. D)

Cancer nadaensis SASAKI, 1969, p. 258, text-fig. 7 ; 1976, p. 319, text-fig. 175; NATIons, 1975, p. 76 , fig. 5 , carapac, dorsal view, fig. 6 , right cheliped, outer view.

Material examined:

1 우 , egg-bearing, off Hayama, coll. by H. IKEDA by crab-pot, 1981.

1 우, juv. same locality coll. by the same collector, 1982 .

The carapace of the young specimen is more thickly covered with minute granules than in the adult one. The posterolateral borders are also sharply denticulated than in the adult specimen (cf. Pl. VI, fig. D).

\section{On phantasmic Cancer balssi SAKAI, 1972.}

While I was studying the crabs of Sagami Bay, I noticed that Platepistoma anaglyptum BALSS, 1922 may be a crab of Cancer near C. oregonensis of U.S.A., not Hawaiian Platepistoma. And I hoped to remove this species to the genus Cancer. But when this book (1965) was almost completed, I again noticed that Cancer anaglyptum was formerly used as the previous name of Etisus anaglyptum. As I had no time to change this name, I only incerted a foot-note on page 105 that this name will be change in near future in a separate paper.

Dr. J.D. NATIONS of U.S.A. was studying Cancer at that time, and was prepareing a monograph for fossil and recent Cancers from Natural History Museum of Los Angeles, Calif. U.S.A. He asked me by letter, the changed name of Cancer, and I answered him that changed name may be Cancer balssi SAKAI and he accepted it. But at that time, TAKEDA and MIYAKE published a small paper and in its short preface, seeing my footnote of 1965, and without notice me, changed the Cancer name into Cancer sakaii TAKEDA and MiYake. I was surprised by this name, and hastily wrote to Dr. NATIONS this fact. $\mathrm{He}$ was lucky in time to change the former name, but to say sorry the old name, with its photo of carapace and cheliped, remained without change on page 68 .

That is why one species of Cancer bears two names-Cancer balssi and Cancer sakaii. 
Fam. Portunidae Rafinesque, 1815.

Caphyra minabensis New Species.

(P1. V, Fig. B)

Material examined:

1우, holotype, Kii Minabe, associated with a soft coral, Microspicularia digitulata (KLUnzINGER). Obtained by the author from the wastes of the lobster-net, March 1979.

The genus Caphyra has been represented by two species in Japan, viz.,

Caphyra yookadai SAKAI, 1933.

Japan, Izu Peninsula, Kii Peninsula, Australia and Indian Ocean.

$$
\text { C. rotundifrons A. Millne EDWARDS. }
$$

Japan, Hachijyo Is., Mariana Is., Samoa, New Caledonia, Mauritius and Madagascar.

The third and new species has been obtained by the author at Kii Minabe, and will be described in the following.

The new species is related to Caphyra unidentata LENZ, 1910 from Madagascar, but the carapace is much broader than it. The carapace is white and glossy, no color patterns. The front is transversely waved, medially divided into two, each of which is again divided into two. The outer orbital tooth is acuminate and small, behind which is a sharp spine just like the $C$. unidentata. The carapace behind this lateral tooth is divergent and very broad.

The dorsal surface of carapace is faintly ridged behind the frontal and anterolateral teeth; otherwise the carapace is smooth.

In the chelipeds, the dorsal, upper border of palm is bi-carinate. All the dactyli of ambulatory legs are adapted to clinging and the last pair is deviated to the dorsal side.

Measurements: Length of carapace $6.0 \mathrm{~mm}$, width of same $7.0 \mathrm{~mm}$.

\section{Charybdis (Charybdis) anisodon DE HAAN, 1833.}

(P1. I, Fig. 4)

Portunus anisodon DE HAAN, 1833, Fauna Japonica, Crus., p. 42.

Goniosoma anisodon A. Mile Edwards. 1861, p. 381, pl. 33, fig. 4.

Charybdis (Charybdis) anisodon J.E. LeEnE, 1938, p. 64, fig. 27.

Material examined:

$1 \hat{\delta}, 1$ 우, Mangrove of Kuira River, Iriomote Is., Okinawa. Coll. by H. Yoshikawa, Kagoshima Univ., Oct. 1980.

$1 \hat{0}, 1$ 우, Amami Ohshima, informed by the same collector.

This species was early described by DE HAAN in 1833, however, no exact locality of this species in Japanese waters had not yet been recorded. The upper recorded localities 
are exact ones for this species.

Measurements: Length of carapace $26 \mathrm{~mm}$, width of same $46 \mathrm{~mm}$.

Distribution: From Japan, Korea toward Indonesia, India, Red Sea, South Africa and Australia.

Fam. Xanthidae MacLeay, 1838.

Genus Actumnus DANA, 1851.

The Indopacific genus Actumnus comprises about 30 species in all, among which about six species belong to the Japanese fauna, viz.,

Actumnus squamosus (De HAAN, 1835)

A. setifer (DE HAAN, 1835)

A. obessus (DANA, 1852)

A. forficigerus (STIMPSON, 1858)

A. dorsipes (StIMPSON, 1858)

A. intermedius BALss, 1922.

Actumnus dorsipes (STIMPSON, 1858).

(Pl. VI, Fig. 2)

Pilumnus dorsipes Stimpson, 1858, p. 37; 1907, p. 70, pl. 9, figs. 3, 3a.

Not Pilumnus dorsipes Alcook, 1898, p. 197; Borradaile 1902, p. 264 ; Rathbun, 1910, p. 356, pl. 1, figs. 3, 7=Pilumnus sinensis Gordon, 1931.

Actumnus dorsipes SAKAI, 1939, p. 529, pl. 99, fig. 7; 1965, p. 156, pl. 76, fig. 5; 1976, p. 497, text-fig. 266.

Material examined:

$1 \hat{\delta}, 1$ 우, Fukido Gawa, river-mouth, Ishigaki Is., Okinawa. Coll. by Seido OHIsHI, Tsukuba Univ.

1ㅅ, 1우, Kii Minabe, coll by the author, 1975.

Each of the areolae of the carapace is convex and sparsely covered with worn tubercles. The grooves separating these areolae are more clearly defined. Of these areolae, $2 \mathrm{M}$ is small and its outer side is obscurely incised; $3 \mathrm{M}$ is medially defined into two and its anterior end is narrowly projecting. Intestinal region is large and medially divided into two.

The four teeth of the anterolateral broder are margined with tubercles. The areolae of the carapace are more clear than those of the Japanese mainland, and the sharp tubercles of the wrist and palm are rather sparse.

\section{On the species related to Actumnus}

On Actumnus elegans DE MAN, 1887. 
Actumnus elegans De Man, 1887, p. 47; Alcock, 1898, p. 206; Chopra and Das, 1937, p. 408, text-fig. $12,13$.

Not Globopilumnus globosus BaLss, 1933, p. 7, pl. I, figs. 1, 2.

Not Actumus elegans, Takeda and Miyake, 1969, p. 97, figs. 1, 2d, f.

This species was described by DE MAN in 1887 from Mergui Archipelago, but no its figure was given by the original author. Afterwards Alcock (1898) examined this species, and doubted its systematic status and regarded it rather near to Pilumnus scabriusculus (WHITE), but he placed this species in Actumnus as before.

In 1933, H. BALss examined Pilumninae and established a new genus Globopilumnus and its type was designated to Pilumnus globosus DANA, and Actumnus elegans was regarded as synonymous with this species.

In 1937, however, CHOPRA and DAS of Culcutta studied the cotype of Actumnus elegans from Mergui Archipelago, and after compaired these specimens with Pilumnus globosus (=Type of Globopilumnus of BALSs), they confirmed that elegans and globosus are not congeners and opposed to BALss's identification. Thus, Actumnus elegans remains as an independent species. But the carapace of elegans is, according to the figure of CHOPRA and DAS seems to be a different one from Actumnus species.

In 1939, TAKEDA and Mryake reported Actumnus elegans from the sea of Kyusyu, but their species is, according to their figure, quite different from CHOPRA and DAS's figur of Actumnus elegans. The frontal, orbital and anterolateral border of TAKEDA and Mryake's species are not Actumnus species.

\section{On Platypodia digitalis Rathbun, 1907.}

Platypodia digitalis Rathbun, 1907, p. 38, pl. 1, fig. 6, pl. 9, figs. 4, 4a.

Actumnus digitalis TAKEDA and MIYAKE, 1969, p. 101, text-figs. 3, 4.

This species was described by RATHBUN from Tahiti and Caroline Islands, as a species of Platypodia. Afterwards, Bouvier (1915) regarded this species as a congener of Actumnus, and TAKEDA and MiYAKe followed Bouvier.

In the form of frontal, orbital and anterolateral borders, this species agrees well with Platypodia, and the immovable finger of cheliped has a broad tooth near the base, as in Platypodia tomentosa or P. semigranosa (cf. RathBun's paper).

The dorsal surface of carapace of digitalis is however, peculiar, the protogastric area being large and transversely ovate, not longitudinally elongate as in that of Platypodia species. The male abdomen of digitalis is composed of seven distinct segments, while that of Platypodia is composed of five pieces, the third to fifth segments being fused together.

As a conclusion, the author thinks that the digitalis may belong to a new distinct genus intermediate between Platypodia and Actumnus. 
On Pilumnus marginatus Stimpson, 1858.

Pilumnus marginatus Stimonson, 1858, p. 37; 1907, p. 70, pl. 9, fig. 2; Balss 1933, p. 12; YoKoYa, 1933, p. 185 (?, not seen); SAKaI 1939 (after Yokoya's paper).

Not Pilumnopeus marginatus TAKeda and Miyake, 1969, p. 120, text-fig. 10.

This species was described by STIMPSON from Okinawa with a figure of entire animal. No second specimen has yet been obtained. Its type specimen is not extant, the specimen being lost by the great fire of Chicago. According to his posthumous figur, however, the areolae of the carapace and the anterolateral borders, this species resembles Actumnus, but the wrist and palm of chelipeds are not tuberculated and the ambulator legs are slender like those of the genus Pilumnus.

TAKeda and Mryake transfered this species into the genus Pilumnopeus in 1969, but their identification seems going too far. Their species has the carapace much broader and covered with long hairs, and no areolae are indicated. Their specimen probably differ from StimpsoN's Pilumnus marginatus.

On Actumnus similis TAKeda and Mryake, 1969.

Actumnus similis TAKeda and Mryake, 1969, p. 109, text-fig. 7.

This species was described from Palau Islands, not belonging to the Japanese fauna. In the characters of the carapace and chelipeds, this species seems to belong to other genus such as Parapilumnus; not to Actumnus.

\section{Analysis of the genus Actaea De HanN, 1833}

Actaea is the large genus, comprising a large number of species in the Indopacific and Atlantic. In 1925, T. ODHNER of Stockholm published a monograph of this genus and described many Actaea species, but in recent years, Dr. Guinot of the Mus. Nat. d'Hist. Naturelle, Paris, studied and analysed this genus, and a number of new genera were established. Such are-Paractaea, Gaillardiellus, Forestia, Novactaea and Serenius etc. The author takes this opportunity to establish two new genera-Lobiactaea and Odhneria, which will be described in the following.

\section{Lobiactaea New Genus.}

The carapace of the new genus is, like that of Actaea, not so broad, the length to breadth being $1: 1.5$. The dorsal surface of carapace is separated into fine areolae, each of which is covered with tubercles the setae. Of the gastric area, $3 \mathrm{M}$ is divided into two in the form of $\mathrm{U}, 3 \mathrm{M}$ and $1 \mathrm{P}$ are large and flat, otherwise, remained areolae are round and convex, covered with granules and setae.

The chelipeds are subequal, the arm is depressed and the anterior edges are separated 
into four or five granulated teeth; the upper and outer surfaces of the wrist and palm are covered with independent nodules, each of which is covered with tubercles and setae.

The apex of 1 st pleopod of male is, like that of Actaea, curved inwards at tip and bears several long hairs.

Lobiactaea lobipes (ODHNER, 1925).

(Pl. II, Fig. 2; Pl. VIII, Fig. B)

Actaea lobipes Odhner, 1925, p. 44, pl. 3, fig. 2.

Gaillardiellus lobipes, 1980, p. 83.

Material examined :

1\}. Suzaki, Izu Shimoda, coll. by His Majesty, The Emperor of Japan, Nov. 1977.

1 우, same locality, Izu Shimoda, coll. by His Majesty the Emperor of Japan, Jan. 1978.

1个̂, Izu Shimoda, Marine Park, coll. by S. Nagai and brought by H. IKedA on Jan. 1978.

Measurements : Length of carapace $10 \mathrm{~mm}$, width of same $14.5 \mathrm{~mm}$.

Distribution: Izu Shimoda Japan and Macclefield Bank, South China Sea.

\section{Odhneria New Genus}

Type species: Odhneria acutidens New Genus, New Species.

The carapace of this new genus is a little broader than long, compared with that of Actaea, the proportion between length to breadth being $1: 1.5$, while that of Actaea $1: 1.4$. The dorsal surface is elegantly separated into areolae by deep grooves. Each areolae are covered sparingly with conical tubercles of various sizes. In the gastric area, $2 \mathrm{M}$ is longitudinally divided into two elongate lobules. The front is deeply bilobate, each one of which is margined with tubercles. The anterolateral border is cut into five teeth, each of which is covered with tubercles and its top is larger and pointed.

Chelipeds are large and the wrist and palm are massive but not separated into lobules and are covered with conical tubercles of various sizes.

\section{Odhneria acutidens New Genus and Species.}

$$
\text { (P1. II, Fig. 3; Pl. VII, Fig. D) }
$$

Material examined:

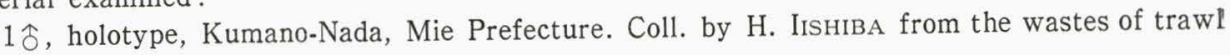
nets.

Carapace is elegantly separated into numerous areolae by deep grooves, each of the areolae is covered with conical and independent tubercles of various sizes. The front is deeply bilobate and their margines are tuberculated, and the upper orbital eave is also thickly tuberculated. Among the frontal and gastric areas, $1 \mathrm{~F}$ is rather rounded, $1 \mathrm{M}$ 
is high, and $2 \mathrm{M}$ is composed of two longitudinal areolae ; $3 \mathrm{M}$ is separated into four small areolae, of which, the anterior one is very narrow and elongate, the next two are divided into two side by side and the last one is transverse. $4 \mathrm{M}$ and $1 \mathrm{P}$ are conjugated.

The anterolateral border is composed of five teeth, the first or external orbital one is small, the second to fifth one are large and covered with tubercles, the top one of which is large and acuminate. An oblique groove extends from between the fourth and fifth anterolateral teeth toward the intestinal area, the inner margin of which is arranged with several larger tubercles.

Chelipeds are massive, the wrist is armed with two teeth at the inner outer extremities; the surface of the wrist and palm are not separated into areolae and their exposed surfaces are sparingly covered with conical tubercles.

The male abdomen is composed of seven distinct segments; the 1 st pleopod is slender, and its tip slightly hooked and bearing several long hairs.

Measurements: Length of carapace $16 \mathrm{~mm}$, width of same $23 \mathrm{~mm}$.

Distribution: Known only from Kumano Nada, Mie Prefecture.

\section{Odhneria echinus (ALCOCK, 1898)}

$$
\text { (Pl. II, Fig. 1) }
$$

Actaea echinus Alcock, 1898, p. 149; Illus. Zool. Invest. Crust., pl. 37, fig. 3; SAKAI, 1965a, pp. 40,44 , pl. 6 , fig. 11 .

Actaea nodulosa var. echinus Odhner, 1925, p. 57, pl. 5, fig. 11.

Material examined:

$3 \hat{\circ} \hat{0}, 2$ 우우, Kii Nagashima, coll. by the student of Nagashima High School, 1975.

3소, 2 우우, Kii Minabe, coll. by the author and M. OzAKI, 1975.

1\}, Kumano Nada, coll by H. Isshiba from the wastes of trawl nets.

This species was already reported by the author in 1976, however, a figure of an entire animal from Kumano-Nada is show hierwith.

Measurements: Length of carapace $23 \mathrm{~mm}$, width of same $34 \mathrm{~mm}$.

Distribution: Kumano-Nada and Kii Province, and India.

\section{Genus Platypodia BeLL, 1835.}

This genus has been represented by three species in Japanese waters, viz.,

Platypodia granulosa, RÜPPELL, 1830.

P. semigranulosa, Heller, 1861.

P. anaglypta, HeLleR, 1861.

In the present opportunity, another one species, $P$. tomentosa is added to the Japanese fauna from Ise Bay and Kumano-Nada. 
Platypodia tomentosa DE MAN, 1888.

(Pl. II, Fig. 4; Pl. VIII, Figs. A, $\mathrm{A}_{1}$ )

Lophactaea semigranosa, (partim.) DE MAN, 1888, p. 465, pl. 8, fig. 4, 4a.

Lophactaea tomentosa, DE MAN, 1902, p. 585.

Platypodia tomentosa, Buitendijk, 1941, p. 309, fig. 3c.

Material examined:

2全令, 2 우, Wagu, Ise Bay, coll. by N. Yamashita faom the wastes of the lobster-nets.

1 우, Kumano Nada, Mie Prefectue, coll. by H. IsshiBa from the trawl nets.

Some of the areolae of the carapace are ornamented with a bundle of long hair. In the areolae of the dorsal surface of the carapace, $1 \mathrm{~F}$ and $2 \mathrm{~F}$ are conjugated, $1 \mathrm{M}$ is convex, and these are also covered thickly with granules.

There is a large, characterized tooth near the base of the immovable finger, the free edge of which is separated into three small teeth.

Measurements: Length of carapace $17 \mathrm{~mm}$, width of same $25 \mathrm{~mm}$.

Distribution: Wagu and Kumano-Nada, Mie Prefectue and Indian Archipelago.

Platypodia semigranosa (HELleR, 1861.)

(P1. VII, Figs. B, $B_{1}$ )

Atergatis semigranosus, Heller, 1861, p. 6: 1861a, p. 313.

Lophactaea semigranosa, АLсоск, 1898, p. 101.

Platypodia semigranosa, BuitendiJK, 1941, p. 308, fig. 3b; SAKaI, 1976, p. 405, pl. 144, fig. 3.

This species was already reported by the author (1976), however, the figure of part of the carapace and the characteristic tooth of the immovable finger of the cheliped are figured in Pl. VIII, figs. B, $\mathrm{B}_{1}$.

\section{Genus Serenius GuINoT, 1976.}

This genus has been established by Dr. D. GuINoT for the memory of the late Dr. R. SERÈnE of the Museum National d'Histoire Naturelle in Paris. Serenius comprises five species in all, two of which are described in Japanese waters, viz.,

Serenius gemmula (DANA, 1852),

S. ceylonicus (LAURIE, 1906).

Serenius gemmula (DANA, $1 £ 52$

$$
\text { (P1. II, Fig. 5) }
$$

Zozymus gemmula, DANA, 1852, p. 190, 1855, pl. 9, fig. 6a-e.

Zosimus gemmula, Guinot, 1967, p. 561; 1971, p. 1071.

Serenius gemmula, Guinot, 1976, p. 275, fig. 38 C, 46 E, pl. 17, fig. 5. 
Material examined:

1\}, Kumano-Nada, Ryugushi, Coral Reef, coll. by H. IIsHiba.

This species is obtained for the first time in Japanese waters. The carapace is broader than long and the front slightly projected in the middle. The anterolateral border is crested with a plate-like margin, which is marked with three closed fissures. Chelipeds and ambulatory legs are, like the anterolateral border elegantly separated in areolae and covered with granules.

Measurements: Length of carapace $18 \mathrm{~mm}$, width of same $26.5 \mathrm{~mm}$.

Distribution: Japan, Kumano-Nada and Indonesia.

\section{Nanocassiope granulipes (SAKAI, 1939).}

(Pl. III, Fig. 1; Pl. VII, Fig. C)

Heteropanope granulipes, SAKAI, 1939, p. 546, text-fig. 59; SERÈnE, 1964, p. 185, pl. 16, fig. A, text-fig. 1.

Micropanope granulipes, SAKAI, 1965, p. 139, pl. 70, fig. 2.

Nanocassiope granulipes, GuINot, 1967, p. 355; 1971, p. 1075; SAKAI, 1976, p. 433, pl. 156, fig. 2 .

This tiny Xanthoid crab is very commonly living on the bottoms off the coast of Kumano-Nada, the 1 st male pleopod of this species is figured hierwith. Among the numerous specimens, the largest male is figured in pl. III, fig. 1.

Measurements: Length of carapace $10 \mathrm{~mm}$, width of same $16 \mathrm{~mm}$.

Distribution: Japan, Sagami Bay, Kumano-Nada, East China Sea and South Africa.

Fam. Goneplacidae MacLeay, 1838.

Genus Beuroisia Guinot, 1978.

Beuroisia major (SAKAI, 1978.)

(Frontispiece, Fig. 1)

Neopilumnoplax major SAKAI, 1978, p. 8, pl. II, fig. A, fig. 16, 16a, 17.

Beuroisia major, Guinot and B. Richer De Forges, 1980, p. 244, pl. IV, figs. 4, 5, 5a.

Material examinec:

$1 \hat{\delta}$ (type specimen) and 1 우 (allotype), Kimmei Sea Mount, Central Pacific.

1\}, off Manazuru, Sagami Bay, coll. by H. IKEdA, 1978.

1\}, 1우, off Ohiso, Sagami Bay, coll. by IKEDA, 1982.

1\}, Wagu, Ise Bay, coll. by N. YAmashita, by Chibike-Ami, 1981.

Distribution: Kinmei Seamount, Central Pacific, Sagami Bay, and Ise Bay.

Intesius pilosus GuINot and B. RICHER DE Forges, 1980.

(Frontispiece Fig. 2) 
Intesius pilosus, Guinot and B. Richer DE Forges, 1980, p. 253, fig. 6D, fig. 11A-G; pl. VII, 1, 1a, 1b; SAKAI, 1982, Aquabiology, vol. 4, no. 5, A figur of the cover of the volume.

Material examined:

1\}, Wagu, Ise Bay, coll. by N. Yamashitaby Chibiki-ami, 200 metres deep. Oct. 1981.

1 우, same locality, same collector, Jan. 1982.

Measurements: Length of carapace $35.2 \mathrm{~mm}$, width of same $42 \mathrm{~mm}$.

Distribution: This species was collected for the first time from the Island Loyauté, recif Jouan $300 \mathrm{~m}$. deep, and studied by Dr. Guinot and B. Richer DE Forges. Ise Bay is the second record of distribution for this species.

Fam. Pinnotheridae De HaAn, 1833.

Sakaina japonica SERÈnE, 1964.

$$
\text { (PI. VI, Fig. A) }
$$

Sakaina japonica SERÈne, 1964, p. 273, text-fig. 22, pl. 24, fig. B; SAKAI, 1965, p. 180, pl. 88, fig. 3 ; 1976, p. 580 , pl. 201, fig. 2 ; text-fig. 319 .

Material examined:

1\}, 1 우, Kumano-Nada, coll. by H. IISHIBA from the wastes of trawling nets.

Besides the Sagami Bay, this is the first locality for this species. The entire animal of male has been figured on Pl. VI, fig. A of this paper.

Fam. Ocypodidae RafinesQue, 1815

Subfam. Camptandriinae Stimpson, 1858

Camtandrium sp.

(Pl. VI, Fig. C)

Material examined:

One young specimen, which is not sexually growned obtaind from the mangrove at Kuira River, Iriomote Is., Okinawa. Coll. by H. Yoshikawa, Kagoshima Univ.

According to MANNING and Holuhuis (1981), the type of Camptandrium sexdentatum STIMPSON is the only representative of Japanese fauna. The present specimen is, therefore, the second one of this genus in Japan. The specimen is too young and the male abdomen and its 1 st pleopod can not be examined. The sculpture of carapace of the present specimen is closely related to the known species-Camptandrium starmuehlneli Prezmann, C. ambonensis SERÈnE and MoosA, and C. rathbunae TAKEDA. Whether the Okinawa specimen is different or synonymous withe the species alrady reported, we must wait until the adult specimen of Okinawa could be examined.

Measurements: Length of carapace $3.3 \mathrm{~mm}$, width of same $3.4 \mathrm{~mm}$. 
Genus Deiratonotus Manning and Holthuis, 1981

This genus has been created by MANNING and HolTHUis in 1981 to accommodate two already known species, which have the fourth male abdominal segment is strongly narrowed, and the 1 st, male pleopod bent strongly proximally and pointed.

This genus is represented by three species, one of which is new to science and obtained from Kii Province, viz.

Deiratonotus cristatum (DE MAN, 1895) ..............Japan, Korea and China. (Formerly Paracleistostoma cristatum DE MAN.)

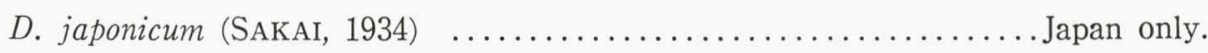

(Formerly Paracleistostoma japonicum SAKAI)

D. tondensis New Species............................... Province.

Deiratonotus tondensis New Sspecies.

(P1. VIII, Figs. D, $\mathrm{D}_{1}, \mathrm{D}_{2}$ )

A small species and its habitat is just like that of Deiratonotus japonicum SAKaI, living on the flats of river mouth.

The carapace is flat and anteriorly broadened. Against the generic name of this species (Deirato=ridged, notus=dorsum, after MANNING and HolTHuIs), the dorsal surface is flat and no ridges on the gastric and cardiac regions. The anterolateral border is cut into two or three obtuse teeth. The ischium and merus of the outer maxilliped are very broad, so that the buccal orifice is completely closed.

The tips of the fingers are spoon-shaped, by their aid, the animal can pick up the mud for select the organisms for food. In the ambulatory legs, the posterior border of merus of the first to fourth pairs, and the carpus of the third and fourth pairs are covered with soft hairs on the upper surface.

The first and second segments of the male abdomen are very short, and the third to fourth segments are fused together, and the fifth segment is narrowed in the distal portion. The anterior male pleopod is strongly bent basally and pointed, without long hairs.

Measurements: Length of carapace $8.5 \mathrm{~mm}$, width of same $11 \mathrm{~mm}$.

Distribution: Known only from Kii Province.

Fam. Grapsidae MacLeay, 1838.

Genus Iliograpsus BARNARD, 1954.

In 1910, Mary Rathbun described a species-Camptandrium paludicola from the coast of Thailand, and afterwards, BARNARD established a new genus to accomodate RATHBUN's species, which is different from the true Camptandrium, and another new species, Iliograpsus rhizophora, was described. 
According to Crosnien's study, however, Iliograpsus rhizophora is only synonymous with $I$. paludicola, so that Iliograpsus is now represented by a single species-I. paludicola. In my recent collection, there is a young specimen of Iliograpsus obtained from the mangrove of Kuira River, Iriomote Is., Okinawa. This specimen seems to be a new species, and will be described in the following.

Iliograpsus nodulosus New Species.

$$
\text { (Pl. VI, Fig. E) }
$$

Material examined:

1 young specimen, sex unknown, at the Mangrove of the Kuira River, Iriomote Is., coll. by H. Yoshikawa of Kagoshima University, Oct. 1980.

The carapace is a little broader than long. The front is obtusely bilobate, the median fissure is very shallow. The dorsal surface of carapace is uneven; immediately behind the frontal lobes, there is a pair of ridges and their outer edge is turn anteriorly and connected with the anterior edge of the orbital eave. Immediately behind these ridges, a pair of obscure nodule are present. In the gastric area, $3 \mathrm{M}$ is obscure, and behind, which a pair of small, rounded lobules are seen. The intestinal area is a little larger, represented by a small nodule. The hepatic and inner branchial areas are represented by small nodules, the former with a single and the latter with two oblique ones.

The anterolateral border is composed of four sharp teeth, of which, the first or outer orbital one is very large, the second one is very small, the third one very large and the fourth is very small. The difference of size in these teeth are just like those of Iliograpsus paludicola (RATHBUN). Along the posterolateral and posterior margines, there are rows of short intermitting ridges, otherwise, the surface of carapace is smooth.

The chelipeds and ambulatory legs are fallen off, also the 1 st male pleopod is not seen.

Measurements: Length of carapace $3.9 \mathrm{~mm}$, width of same $4.2 \mathrm{~mm}$.

Known only from Iriomote, Okinawa.

\section{Metopograpsus latifrons (WHITAE, 1847).}

$$
\text { (P1. III, Fig. 2) }
$$

Grapsus latifrons White, 1847, Jukes' Voy. "Fly" v. 2, p. 337, pl. 2, fig. 2. (not seen).

Metopograpsus latifrons Tesch, 1918, Siboga Monographie xxxcx c, p. 81; BanerJeE, 1960, p. 177 , figs. 4 j, 5 d, $6 \mathrm{a}$; SAKaI, 1980 , p. 78.

Material examined:

$1 \hat{ᄋ}, 1$ 우, at the Mangrove, the Kuira River, coll. by H. Yoshikawa of the Kagoshima Univ.

This species is very closely related to Metopograpsus oceanicus from Palau Islands, but the lateral margin has no tooth behind the outer orbital one. 
Measurements: Length of carapace $25 \mathrm{~mm}$, width of same $30 \mathrm{~mm}$.

Distribution: This species ranges from southern Japan to Indo-Pacific, South India and New Caledonia.

\section{Neoeriocheir New Genus.}

Type species: Eriocheir leptognathus RATHBun, 1913.

The genus Eriocheir comprises four spcies until now, viz.,

Eriocheir japonicus DE HAAN, 1833.

E. sinensis H. Milne Edwards, 1853.

E. rectus STIMPSON, 1858.

E. leptognathus Rathbun, 1913.

Of these four species, the first three are true Eriocheir and their body is dark greenish and punctate, but the last named species is small and the color is pale blueish and its dorsal surface is smooth and thin, not at all punctate. In true Eriocheir, the wrist and palm of chelipeds are thickly covered with long and soft hairs both on outsr and inner surfaces, while in the new genus the outer surface is smooth and glossy. The external maxillipeds of the new genus are rather slender, especially the merus is longer compred with that of Eriocheir, and the buccal cavern of the new genus is not completely closed.

Neoeriocheir leptognathus (RATHBUn, 1913).

(Pl. III, Fig. 3; Pl. VIII, F)

Eriocheir leptognathus Rathbun, 1913, p. 353, pl. 33, figs. 2.3 (Shanghai); Kemp, 1918, p. 232; Tesch, 1918, p. 107; Balss, 1922, p. 152; Urita, 1926, p. 433; SAKaI, 1935, p. 6; Panning, 1938, p. 106; Kamita, 1938, p. 383, fig. 3; SaKai, 1939, p. 671, pl. CIX, fig. 2; 1976, p. 649 , fig. 356 .

Utica sinensis PARISI, 1918, p. 102, text-figs. 3, a-d, pl. VIII, fig. 1.

Eriocheir rectus Shen, 1932 (nec Stimpson 1858), p. 178, text-figs. 111-113; pl. VII, fig. 6.

The entire animal is small and gentle-looking compared with the three other species of Eriocheir. The carapace is convex on anterior surface and not punctate. The frontal margin is transversely straight. The anterolateral border is cut into three teeth, the first or outer orbital one is large and strongly convergent, and the posterior two are stright and parallel to the margin of opposit side. No fourth tooth is present, only a granulated ridge runs from the position of the fourth tooth toward the posterolateral portion.

The external maxillipeds are slender, especially the merus is longer than that of Eriocheir and the buccal cavern is not completely closed.

In the chelipeds, outer sides of wrist and palm are smooth and glossy, not at all hairy. The inner surface of these segments are covered with soft, long hairs, just like 
those of Eriocheir or Ptychognathus. The ambulatory legs are slender; the second and third pairs are longer than the first and fourth pairs. The upper surface of the carpus, propodus and dactylus of these legs are marked with a row of hairs along the anterior margin, and such hairs are present parallel to the posterior margins.

Measurements: Length of carapace $22 \mathrm{~mm}$, width of same $22.5 \mathrm{~mm}$.

Distribution: North China, Korea, Yellow Sea side, and Saga, Mouth of Shioda River, Japan.

\section{Literature cited}

Aquabiology, 1982. 4(5) : cover.

Alcock, A., 1898. Materials for a Carcinological fauna of India, No. 3. Brachyura Cyclometopa, Part 1. The family Xanthidae. Jour. Asiat. Soc. Bengal: 67-233.

Balss, H., 1922. Ostasiatische Decapoden, IV. Die Brachyrynchous Cancridae. Archiv. Naturgeschichte, $88,0^{\circ} 11$, pp. 94-166.

1933. Beiträge zur Centniss der Gattung Pilumnus (Crustacea Decapoda) und Vernandter Gattungen mit 35 figuren auf und 7 Tafeln und 5 Text-figuren (Capita Zoologica).

Barnard, K.H., 1955. Addition to the Fauna-list of South Africa and Pycnogonida. Ann. S. Afr. Mus., vol. XVIII, pl. 1, pp. 1-107, fig. 1-53.

BeutendiJK, A.M., 1941. Biological results of the Snellius Expedition. XIII, On some Xanthidae, chiefly of the genus Platypodia Bell. Temminckia 6, pl. 1, figs. 1-3, pp. 295-312.

BanerJeE, S.K., 1960. Biological results of the Snellius Expedition. XVIII. The genera Grapsus, Geograpsus, and Metopograpsus (Crustacea Brachyura). Temminckia V. 10, Figs. 6, pp. 133-199.

ChoprA, B. and DAs, K. N., 1963. Further notes on Crustacean Decapods in the Indian Museum. IX. On three Collections of Crabs from Tavoy and Mergui Archipelago. Rec. Indiau Mus., vol. 39 , pl. 4, pp. 377-434, figs. 1-21, pl. vi.

Crosnier, A., 1965. Fauna de Madagascar. XIII. Crustacés Decapodes, Grapsidae et Ocypodides, 18: 1-143, figs. $1-260$, pls. I-XI.

Dana, J.D., 1852. Crustacea. United States Exploring Expedition during the years 1838-1842 under the Command of Charles WiLkes, U.S.N. vol. 13, pl. 1, 1852, p. viii, 1-685.

1855. Crustacea. United States Exploring Expedition during Years 1838-1842 under the Command of Charles WiLkES, U.S.N. Atlas 1-27, pl. 1-96. Philadelphia.

Edwards, A.M., 1861. Etudes Zoologiques sur les Crustacés récents de la famille des Portuniens. Arvhiv. Mus. d'Hist. nat. vol. x. pp. 309-428, pls. 28-38.

Guinat, D., 1976. Constitution de quelques groupes naturels chez les Crustacés Décapodes Brachyures. 1. La superfamille des Bellioidea et troi sous-familles de Xanthidae (Polydectinae Dana, Trichiinae De HaAn, Actaenae). Memoirs du Museum National d'Histoire Naturelle, Nouvelle serie, série A, zoologie.

1967a. Recherches préliminaires sur les groupements naturels chez les Crustacés Décapodes Brachyoures. III. A propos des affinités des genres Dairoides StebBing et Daira De HaAn. Bull. Mus. natn. Hist. nat., Paris, (2e) 39(3): 540-563, figs. 1-36.

- 1971. Recherches préliminaires sur les groupements naturels chez les Crustacés Décapodes Brachyoures. VIII. Synthèse et bibliographie. Bull. Mus. natn. Hist. nat., Paris, (2e) 42(5): 1063-1090.

et B. Richer DE Forges, 1980, 1981. Crabes de profondeur, nouveau ou rares, de l'IndoPacifique (Crustacea, Decapoda, Brachyura) (Premiere partie, 1980, pp. 1113-1153, fig. 53, pl. 7, Deuxieme partie,1981, pp'227-260, figs. 12.

Heller, C., 1861. Synopsis der im rothen Meeres vorkommenden Crustaceen. Verh. zool.-bot. Ges. Wien, 11: 3-32. 
1861a. Beiträge zur Crustaceen-Fauna des rothen Meeres. I. Silz.Ber. Akad. Wiss. Wien. math.-phys. Kl., $43(1):$ 297-374, pls. 1-4.

Ihle, J.E. W., 1913. Dromiacea: Die Decapoda Brachyura der Siboga-Expedition, Siboga Expedite, 39 (b) : 1-96, figures 1-38, plates 1-4.

1916. II. Oxystomata, Dorippidae. Die Decapoda Brachyura der Siboga-Expedition. Siboga Expeditie, Monograph. XXXIXb, livr. 78, p. 97-158, figs. 39-77.

Kemp, S. W., 1918. Crustacea Decapoda and Stomatopoda. Zoological results of a tour in the Far East, edited by N. Annandale. No. 5. Mem. Asiat. Soc. Bengal, 6: 217-297, 12 text-figs.

Leene, J.L., 1938. VII Brachygnatha: Portunidae. The Decapoda Brachyura of the Siboga-Expedition. Monographie XXXIXc. pp. 1-153, Figs. 1-88.

Lenz, H., 1910. Crustaceen von Madagaskar, Ostafrica und Ceylon. Voeltzkow, Reise in Ostafrika in den Jahren 1903-1905, Band II. p. 539-576, text-fig. 1-4.

Man J.G. de, 1887-1888. Report on the Podophthalmous Crustacea of the Mergui Archipelago, collected for the Trustees of the Indian Museum, Calcutta, by Dr. John ANDERson, F. R.S., Superintendent of the. Parts I-IV. Journ. Linn. Soc. (Zool.), vol. 22, 1887, nos. 136-137, pp. 1-128; vol. 22 , 1888, nos. $138-140$, pp. $129-312$, pls. $1-19$.

1888. Bericht über die im Indischen Archipel von Dr. J. Brock gesammelten Decapoden und Stomatopoden. Arch. f. Naturgesch., Bd. 53, pp. 215-600, pls. 7-22a.

1902. Ergebnisse einer zoologischen Forschungsreise in den Molukken und Borneo, Abh. Senckenberg. Naturf. Ges., Bd. 25, Heft 3, pp. 467-929; Taf. XIX-XXVII.

1907. On the collection of Crustacea, Decapoda and Stomatopoda, chiefly from the Inland Sea of Japan, wuth description of new species. Trans. Linn. Soc. London, London, Zool. (2), vol. 9 , pt. 11 , pp. 11 , pp. $387-454$, pls. $31-33$.

Manning, R.B. and Holthuis, L.B., 1981. West African Brachyuran Crabs (Crustcea: Decapoda). Smithsonian Contributions to Zoology, No. 306, pp. i-xii, 1-379, Figs. 1-88.

Nations, J.D., 1975. The genus Cancer (Crustacea: Brachyura) : Systematics, Biogeography and Fossil Record. Natural History Museum of Los Angeles County Sciens Bulletin 23. pp. 1-104: Figs. 1-42; Tables 1-21.

Odhner, T., 1925. Monographierte Gattungen der Krabbenfamilie Xanthidae, I. Goteborgs K. Vetenskaps och Vitterhets-samhälles Handlingar, series 4, 29(1): pp. 1-92; figs. 1-7; pk, k-5.

PARIsI, B., 1918. I Decapodi giapponesi del Museo di Milano. VI. Catometopa e Paguridea. Atti Soc. Ital. Sci. nat., 57: 90-115, 5 text-figs, 8 pls.

Rathbun, M.J., 1907. Report on the scientific results of the Expedition to the tropical Pacific, in charge of Alexander Agassiz, by the U.S. Fish Commission Steamer "Albatross", X. The Brachyura. Mem. Mus. Comp. Zool. Harvard, 35: pp. 23-74, pls. 1-9.

1910. The Danish Expedition to Siam, 1899-1900. V. Brachyura, D. Kgl. Danske Vidensk. Selsk. Skiifter, ser. 7, 5. pp. 301-367, pls. 1-2, Figs. 1-44.

1913. Descriptions of new species of crabs of the families Grapsidae and Ocypodidae. Proceedings of the U.S. National Mus., vol. 46, pp. 353-358, pls. 30-33.

1937. The Oxystomatous and allied Crabs of America. Bull. U.S. Nat. Mus., 166 : 1278, 47 text-figs, 86 pls.

SAKAI, T., 1939. Studies on the Crabs of Japan. IV. Brachygnatha, Brachyrhncha. Yokendo, Tokyo. : 365-741, figs. 1-129, 42-111 pls., tabl. 1.

1965. The Crabs of Sagami Bay collected by His Majesty the Emperor of Japan. Maruzen, Tokyo. : I-XVI, 1-206 (English) +1-100 (Japanese), text-figs. 1-32, pls. 1-100, 1 map.

1976. Crabs of Japan and the adjacent seas. Kodansha Tokyo. I. English Part, II. Colour-Plates (200 plates), III. Japanese text. pp. 1-773, Text-figs. 1-379, Maps 1-3, pls. 1-251 1978. Decapod Crustacea from the Emperor Seamount Chain. Researches on Crustacea. 8(suppl.) : 1-39, text-figs. 1-27, 1-4 pls, 1 map.

1980. On new or rare crabs taken from Japanes and Central Pacific Waters. Researches on Crustacea, no. 10. 73-84, Frontispiece I, pl. 1, text-figs. 3 
Serène, R., 1964. Papers from Dr. Th. Mortensen's Pacific Expedition 1914-1916, 80: Goneplacidae et Pinnotheridae, Récotles par le Dr. Mortensen. Videnskabelige Meddelelser fra Dansk naturhistorisk Forening $i$ Kjpbenhavn, 126: 181-282, figs. 1-22, pls. 16-24.

and Lohavanijaya, P., 1973. The Brachyura (Crustacea: Decapoda) coll. by the Naga Expedition, including a reviw of the Homolidae. Naga Report vol. 4, part 4. pp.-186; pl. 1-xxi.

Shen, C. J., 1932. The Brachyuran Crustacea of North China. Zoologia Sinica, ser. A, Invertebrates of China. pp. 1-320; text-figs. 1-171; pls. I-X.

Stimpson, W., 1907. Report on the Crustacea (Brachyura and Anomura) collected by the North Pacific Exploring Expedition, 1853-1856. Smithsonian Miscellaneous Collections, Part of volume XLIX. pp. 1-240; pls. 1-26.

TAkeda and Mryake, 1969. Pilumnid Crabs of the Familie Xanthidae from the west Pacific. II. Twenty one species of the four genera, with descriptions of four new species. Occasional Papers of Zoological Laboratory, Faculty of Agriculture, Kyushu Univ. pp. 93-156, Figs. 118.

Tesch, J.J., 1918. The Decapoda Brachyura of the Siboga Expedition. I. Hymenosomidae, Retroplumidae, Ocypodidae, Grapsidae and Gecarcinidae. Siboga Exp., 39c: 1-148, pls. 1-6.

URITA, T., 1926. A check-list of Brachyura found in Kagoshima Prefecture, Japan. The Tsingtao Times, Tsingtao: I-IV, 1-41, 1 map.

White, A., 1947. Descriptions of a new genus and five species of Crustacea. In: Jukes, J.B. Narrative of the Surveying Voyage of H.M.S. "Fly" in Torres Strait, New Guinea, and other Islands of the Eastern Archipelago, during the years 1842-46. 2(Append. 8) : 335-338, pl. 1.

Yокоча, Y., 1933. On the distribution of Decapod Crustaceans inhabiting the continental shelf around Japan, chiefly based upon the materials coll. by S. S. Soyo-maru, during the years 19231930. Joun. Coll. Agric. Tokyo, vol. 12. pp. 1-226, figs. 1-71, Tables 1-4.

\section{日本および日本近海のかに類の新属, 新種ならびに}

分類学上分布学上の珍種について (I)

酒井恒

(日本甲殼類学会)

最近数年間に日本拈よび日本近海から採集されたかに類の標本は括びただしい数に上ってい るが，それらの標本の中から新属 4 ，新種 8 を選んでここに報告する。これらの標本は一部は 著者自らが採集し，一部は各地の熱心なる採集家が採集したもので，それらを提供された名前 は標本いちいらに記録してあるがそれらの熱心なる態度に対しては厚い感謝の意を捧げる。ま たこの報文を印刷して下さった小田原甲殼類博物館長，小田原利光博士に対して 深い感謝の意 を捧げる。この報文で扱っている属名種名は次の通りである。

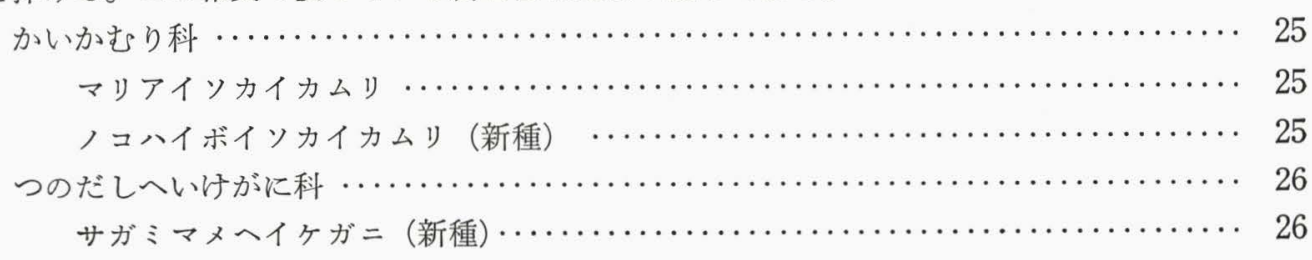


へいけがに科

アシボソマルミへイケガニ

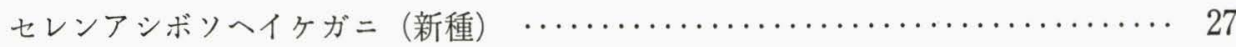

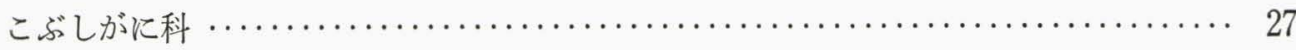

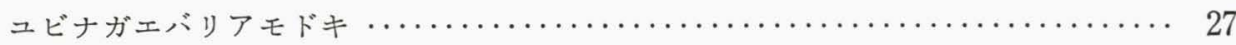

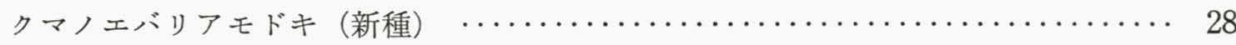

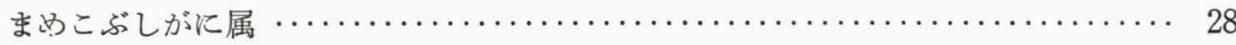

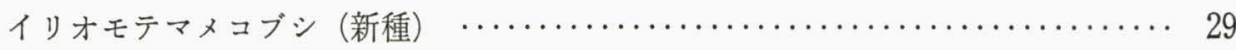

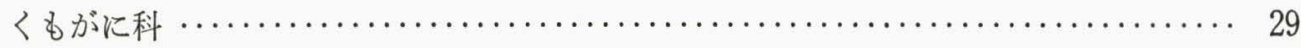

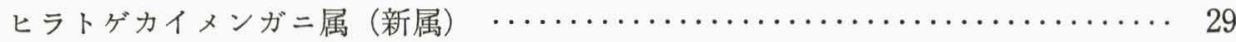

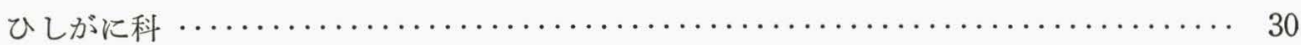

フクレヒシガニ

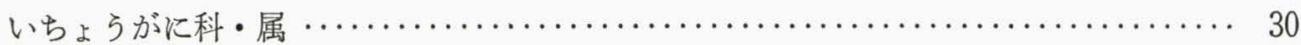

ナダイチョウガニ

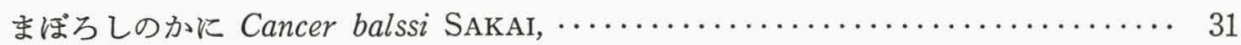

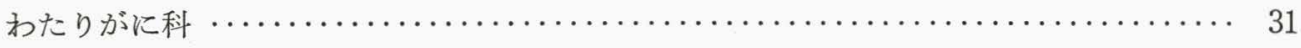

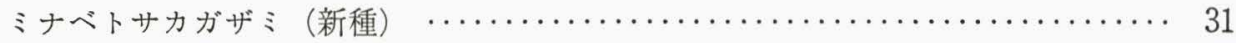

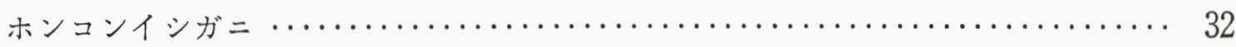

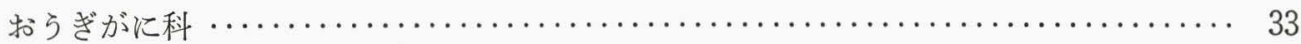

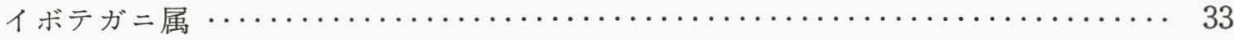

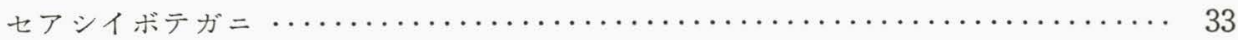

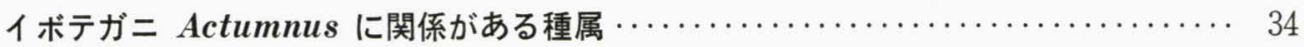

Actumnus elegans DE Man, 1887 そついて。

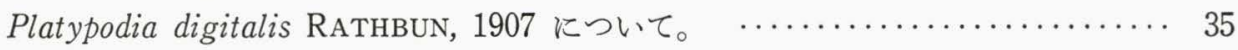

Pilumnus marginatus StIMPSON, 1858 そついて。

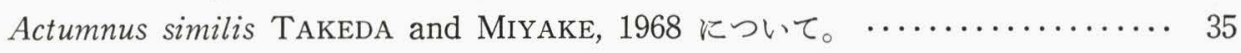

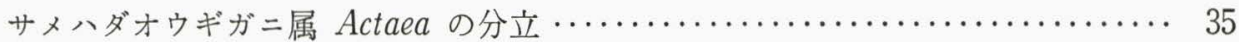

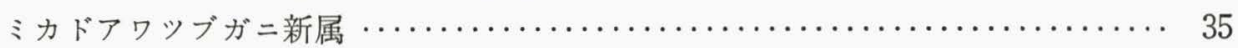

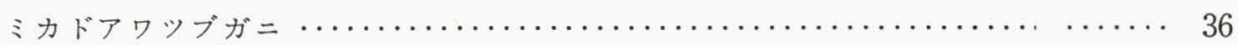

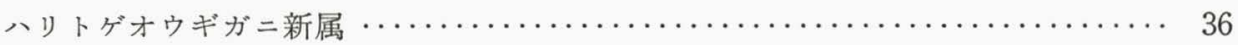

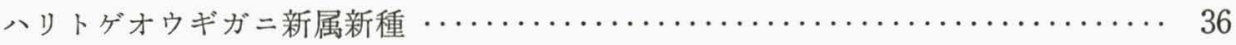

トゲサメハダオウギガ

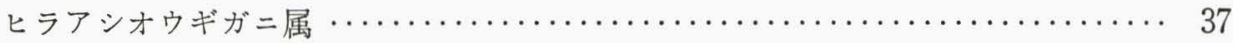

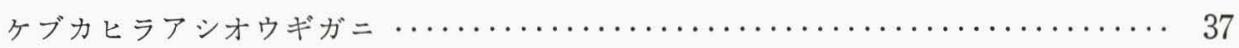

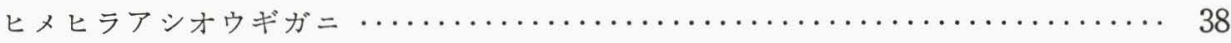

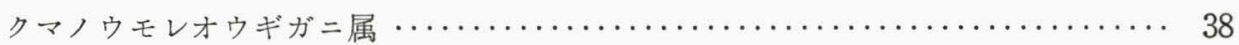

クマノウモレオウギガニ

サガミヒメオウギガニ 


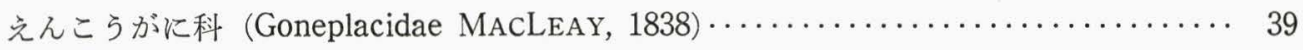

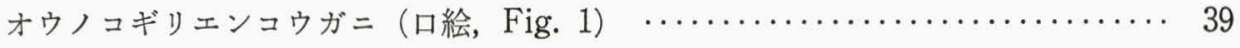

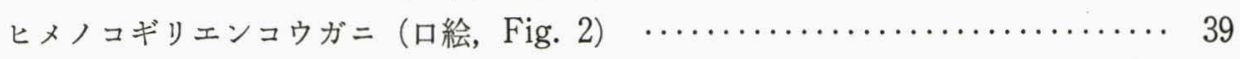

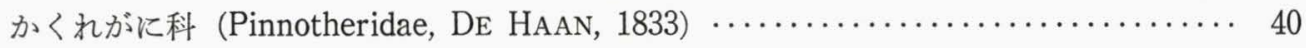

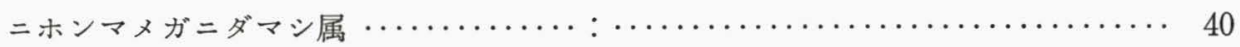

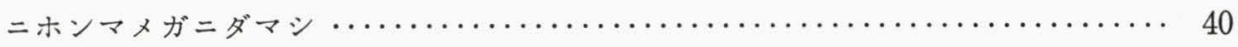

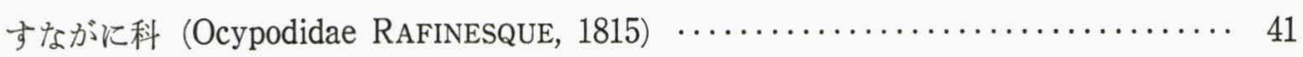

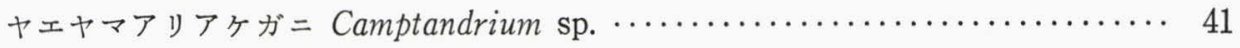

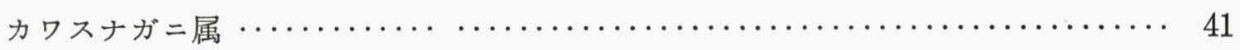

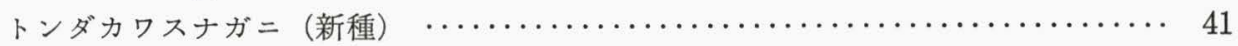

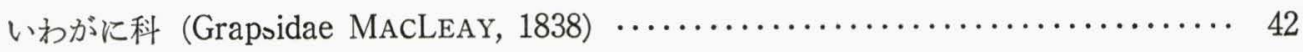

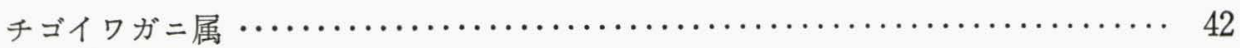

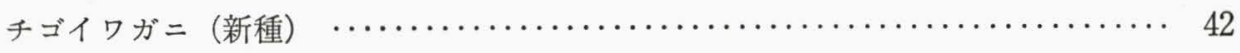

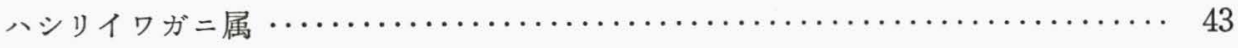

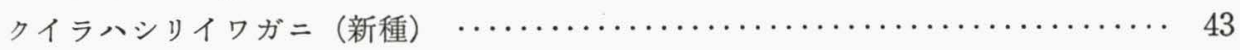

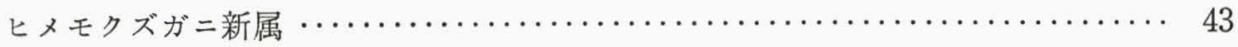

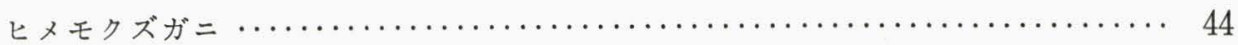

Fam. Dromiddae Alcock, 1899 かいかむり科

Cryptodromia mariae IHLE, 1913 マリアイソカイカムリ

(P1. V, Fig. A)

1个, 2 우 온 紀伊半島潮岬沖 $400 \mathrm{~m}$, 採集者, 飯柴英治。

かいかむり科の中のイソカイカムリ属は日本産 12 種程を含むが本種マリアイソカイカムリは 本邦はじめての記載で, 原産地はニューギニア西部である。故 IHLE 博士の夫人マリア氏の名 前を帯びている。

小形種で甲や胸脚には顆粒も棘もなく平滑である。甲長は僅かに甲幅よりも大で, 額棘はひ ろく左右に分れ中央額棘は殆んど目につかないで短かい。前側縁には小さい眼窩外歯の後方に 1 小歯, 次にやや深い切れこみを隔ててやや大きい第二歯がある。

鉗脚の腕節は外側の中辺と末端に 2 鈍棘, 前節の末端にも 2 鈍棘あり, 歩脚第一・二対の腕 節・掌節は頗る長い。

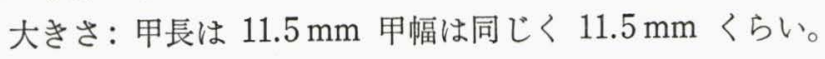

分布：熊野灘及びニューギニア西部

Petalomera acutidens New Species ノコハイボヒラアシガニ 新種

(P1. I, Fig. 2)

本種はイボヒラアシカムリ（Petalomera nodosa SAKAI, 1936) にごく近い種類で甲殼も胸脚 
も突起や隆起が著しく, 前側縁は隆起ではなくて, 鋭い歯がならんでいる。額は著しく前方に 突出して左右に分れ，おのおのが板状で外方に突出している。胃部の 1 対の高い隆起は顆粒に 扮拈われている。胃部は $3 \mathrm{M}^{*}$ 突出し, 鰓部側方の突出も顆粒におおわれている。

本種の最も著しい特徵は, 前側縁が腹面の口廓の隅にまで連りその稜線上に 6 個程の尖った 棘を生じ，そのうち前側縁後方の 4 棘程は顆粒に特おわれていて大きい。

甲殼全面は小域に分れ各小域は顆粒でおおおれているが，甲殼の後方は顆粒を欠き平滑であ る。鉗脚の腕節末端には 2 隆起を生じ掌節末端にも 2 隆起を生じ節の上面には顆粒を生ず。

歩脚は前方 2 対共に各節の末端に 2 個程の隆起を有している。今の腹部第 4 節には 1 対の隆 起があって小顆粒にお㧍われている。

大きさ：甲長 $23 \mathrm{~mm}$ ，甲幅 $26 \mathrm{~mm}$

産地：伊勢湾口和具, 採集者山下信夫氏

Fam. Cymonomidae BouvieR, 1898 つのだしへいけがに科

Cymonomus sagamiensis New Species

サガミッノダシヘイケガニ (新種)

(PI. VIII, Fig. A)

Not Cymonomus andamanicus, Alcock, 1905, p. 568, pl. 18, fig. 1-16, Illus. Invest. Crust. pl. 79 , fig. 2.

Cymonomus quadaratus andamanicus, SAKaI, 1976, p. 37, pl. 8, fig. 1 .

検討標本：

1우, 熊野灘, 採集者飯柴英治, 1975年。

本種は著者が 1976 年に, インドッノダシヘイケガニの名前で相模湾から報告した種と同一で, 甲殼が四角で，側縁前端が角張っていて，にぶく2歯を装っている。Andaman 海産の ALCOCK の種は甲殼が丸味をおびた四角形である点で別種である。また濠州産の Cymopolia delli, GRIFFIN, 1971 は本種に似ているが甲殼や胸脚に小棘や顆粒のない点で別種である。また, Cymopolia umitakae TAKEDA, 1981 は額棘の強大な点で別種である。

Fam. Dorippidae MacLEay, 1838 へいけがに科

Ethusa gracilipes MIERS, 1886 アシボソマルミヘイケガニ

(Pl. IV, Fig. A; Pl. VII, Fig. E)

Ethusa (Ethusina) gracilipes Miers, 1886, p. 332, pl. 29, figs. 1 a-c; AlcocK, 1894, p. 177.

Not Ethusa (Ethusina) gracillips var. robusta Miers, 1886, p. $333=$ Ethusina roousta Miers, 1886.

Not Ethusa gracilipes, Ihle, $1916=$ Ethusa desciscens. (Serene \& Lohavanijaya による)

Not Ethusa gracilipes Rathbun, 1937, Serene Lohavanijaya は E. robusta と同定している が, 脚の短かい別種

* 1M，3M 等の文字は甲域のマークをあらわし，それらはすべて J. DANA 1852 の方式による。 
Not Ethusa gracilipes SERENE \& LohAvAniJAyA.この種は新種で E. gracilipes ではない。後 述のように E. serenei n. sp. である。

検討標本 :

1今, 駿河湾, 深度 2780-2300 m (かに類の生息深度では日本一), 蒼鷹丸にて 梅津武司氏 採集, 1981, Nov. 17)

真の Ethusa gracilipes MIERS, 1886 はフィリッピン近海の原産地と駿河湾の深海のもので あろら。

アシボソマルミヘイケガニの特徵：

甲はやや扁圧していて, 背面の人面模様は不明瞭である。額棘は 4 個の棘のうち左右の 2 個 つつが組をなし中央の切れこみは深く左右の切れこみは浅い。眼窩外棘は細くて長いが額棘の 先端にまでは届かない。触角の髭は頗る長い。

歩脚は頗る細く長くミズヒキガニやトゲミズヒキガニの様装を呈している。前方の第一・二 対の歩脚では，その長節だけについてみても Miers の原図では長さが幅の13倍程あり駿河湾の 標本でもそれに近いが, SERÈNE \& LOHAVANIJAYA の写真図では僅かに 6 倍位で太く短かい。 雄の第一腹肢は本種では太くて先端が丸く毛は縁に少数あるにすぎないが, SERENE \& LOHAVANIJAYA のそれではやや細くて「く」の字に曲り先端に数個の剛毛がある。

大きさ：甲長 $10 \mathrm{~mm}$, 甲幅 $9.5 \mathrm{~mm}$

分布：フィリッピン近海と駿河湾 $2300 \mathrm{~m}$ の深所。

$$
\text { Ethusa serenei New Species セレンアシボソヘイケガニ, 新種 }
$$

Ethusa gracilipes Serène \& LohavaniJaya, 1972, p. 35, text-figs. 56-59; pl. IV C-D.

セレン及びロハヴアニヤーヤ，両博士がアシボソマルミヘイケガニとして同定した標本は東 支那海の標本であるが, 別の新種である, 前節に述べたように歩脚は太くて短かく, 雄の第一 腹肢は太い真すぐの形と異なり, 細くて長く「く」の字形にまがり, 先端に剛毛数本を装って いる。

産地, 南支那海

$$
\begin{aligned}
& \text { Fam Leucosiidae SAmouelle, } 1819 \text { こぶしがに科 } \\
& \text { Genus Praebebalia RATHBUn, } 1911 \text { エバリアモドキ属 }
\end{aligned}
$$

エパリアモドキ属は1911年に Mary RATHBUN (マリー, ラスバン) が中部太平洋から記載し た属で今日までに 8 種が知られていて, その中の 1 種は最近フィリッピンから著者が報告する ものでアルバトロスの採集品記載中， 2 種は飯柴英次氏の 熊野灘からの採集品でその中の 1 種 は新種である。 8 種の名称は次の通りである。

Praebebalia extensiva RATHBUn, 1911

P. pisiformis IHLE, 1918

P. longidactlyla YoKOYA, 1933 ユビナガエバリアモドキ 
P. sikokuensis YOKOYA, 1933 シコクエバリアモドキ

P. mosakiana SAKAI, 1965 モサキコブシガニ

P. taeniata TAKEDA, 1977

P. septemspinosa SAKAI（印刷中） ナナトゲエバリアモドキ

P. kumanoensis New Species クマノエバリアモドキ

Praebebalia longidactyla YoKoYA, 1933 ユビナガエバリアモドキ

(Pl. IV, Fig. 2)

Praebebalia longidactyla Yokoya, 1933, p. 125, text-fig. 44; SaKaI, 1976, p. 77, text-fig. 39. (横屋原図)

検討標本：

1今，熊野灘沖，採集者，飯柴英治氏，1978年

本種は小形種にて原著者の図には何ら色彩の記述はない。熊野灘の標本は小形で乾燥標本で あるが，甲面には茶褐色の交錯した縦縞があり，長い鉗脚にも同色の乱れた環状の色彩が残っ ている。鉗脚の不動指・可動指は截面に小間隔の鋭い突起があり，突起間は刃状であり，指全 体が内屈している。甲殼の額縁も後縁も真すぐに横にきれている。

大きさ：甲長 $5.8 \mathrm{~mm}$, 甲幅 $5 \mathrm{~mm}$

分布：日本産で駿河湾，熊野灘，豊後水道，五島列島。

Praebebalia kumanoensis New Species クマノェパリアモドキ(新種)

(PI. IV, Fig. C)

検討標本:

2 우우, その中の 1 여模式標本に指定, 採集者飯柴英次氏, 1978年

小形の種類で色彩は残っていない。甲殼は前方に突出してせまく，後方に幅広い。甲殼の背 面は密に顆粒で抒括われているが，前端および中央に近く顆粒はやや大きく甲殼の後方拉よび 側方では顆粒は小さい，腸域は僅かに突出し，小顆粒でおおわれている。額縁後縁は横にまっ すぐで, 肝域は僅かに突出している。

鉗脚は細く長く，指部は僅かに内方に偏しており，各節では顆粒は顕著ではない。歩脚は極 めて弱小である。

大きさ：甲長 $5 \mathrm{~mm}$ ，甲幅 $5.5 \mathrm{~mm}$

産地：熊野灘, 採集者, 飯柴英次氏, 1978年。

Genus Philyra LEACH, 1817 マメコブシガニ属

マメコブシガニの属は内湾の砂泥浜から $30 \mathrm{~m}$ 位の海底に産し, 種類も多く, 印度太平洋だ けで実に36種類程を産し，日本の沿岸だけで10種類程を産する。属の特徴として甲殼の肝域が 顆粒で縁どられた菱形の小面を生じ眼窩の後方両側に存在する。

この機会に本属に 1 新種を沖繩西表島のくいら川河口から加える。 
Philyra iriomotensis New Species イリオモテマメコブシガニ

(Pl. IV, Figs. C, $\mathrm{C}_{1}-\mathrm{C}_{3}$ )

検討標本 :

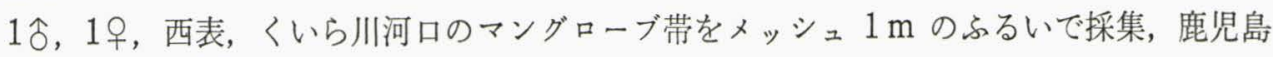
大学の吉川博信採集, 1980, 8 月。

1今, 同じ場所より, 同じ方法で採集, 同大学の長田和人採集。1981

小型のまめこぶしがにで, 甲殼は縦に長く, 菱形を呈し甲殼の周縁は顆粒で縁どられている。 額は突出し, 額縁は中央部でくぼみ甲の後縁は顆粒の縁が 中央部と両端とで突出している。甲 面は中央の, 胃域・心域部で菱形に顆粒でおおおわれ, 甲殸の側面部と後端腸域部で顆粒におお われている。甲殼の他の面は平滑である。肝域の側面はせまく長い小面を形成し，腹部は細く 6 節より成り, 合の第一腹肢の先端には太い長い突出部がある。

大きさ：甲長は $5 \mathrm{~mm}$, 甲幅は $5.5 \mathrm{~mm}$

Fam. Majidae Samouelle, 1819

Paraentomonyx New Genus ヒラトゲカイメンガニ（新属）

Type Species: Entomonyx depressus SAKAI, 1967 ヒラトゲカイメンガニ

(Pl. 1, Fig. 1; Pl. V, Figs. D, $\mathrm{D}_{1}$ )

Entomonyx depressus, SAKAI, 1976, p. 272, text-fig. 149.

本新属は Entomonyx に類似しているが次の諸点で異っている。甲殼は中央で縦に隆起し, 全面大小の顆粒で扮おわれている。1 対の額棘は根元が平たくて僅かに外方に開き先端が球状 に終っていて内側に向う。眼窝上縁即ち眼上板は甚だしく幅広く, 眼窩後棘も頗る幅広く長く, 外縁に 2 個の突起を有し, 両者の間に間棘が短かく底部に存在している。これに対して, Entomonyx 属では板上板と間棘と眼後棘とで管状に外に突出し, 間棘も眼後棘も共に長くて細い。 前側縁のうち, 肝部は幅広くて 2 個の突起に終り前側縁の鰓部では, 4 個の棘が発達し, その 前方の 1 棘は小さいが他はすべて大きく最後の 1 棘は殊に大きく長く, 鰓域の上面にある。こ れらの棘はそれぞれ先端がにぶく丸みをなしている。

甲殼は中央心域部とその後縁末端部にそれぞれ二小棘が並んでいる。これに対し Entomonyx 属では心域の棘は 2 本であるが後縁の棘は中央に 1 個である。

針脚・歩脚は形状が Entomonyx に似ている。雄の第一腹肢は, 近似属であるEntomonyx 属, Chlorinoides 属ではいずれも先端に近く毛と 1 突起とを有するが, 新属では先端が直角にまが り突起も毛もない(Pl. V, Figs. D, 参照)

この新属に属する種は一つで紀伊南部と和具の産である。

大きさ：甲長 (正中線で) $24.5 \mathrm{~mm}$, 甲幅 $19 \mathrm{~mm}$ (䊂を除いて)。 
Fam. Parthenopidae Miers, 1879

Parthenope (Platylambrus) praedator (DE MAN, 1906) フクレヒシガニ

(Pl. I, Fig. 3)

Oncodolambrus praedator De MAN, 1906, Ann. Mag. Nat. Hist. ser. 7, vol. 17, p. 400;1907, p. 389, pl. 31, figs. 1-3.

Lambrus (Oncodolambrus) praedator, SAKAI, 1965, p. 91.

Parthenope (Platylambrus) praedator, SAKAI, 1976, p. 272, text-fig. 149.

検討標本：

1今, 熊野灘沖, 採集者飯柴英次氏，1972年。

この種のかには名前が示すように両鰓域が Bopyrid に犯されて異状にふくれているよらな観 を呈している。原標本は瀬戸内海の西部から採集され，大英博物館に所蔵されているが第二の 産地は熊野灘である。原標本は著者によって正面図が 1976 年に画かれている。飯柴氏の標本は この種の二度目の標本で，その全体の写真がここに揭げてある。

大きさ：甲長 $11 \mathrm{~mm}$, 甲幅 $16 \mathrm{~mm}$, 鉗脚 $29 \mathrm{~mm}$

分布：熊野灘及び瀬戸内海西部。

Fam. Cancridae Latreille, 1803 いちょうがに科

Genus Cancer LINNÉ, 1758 イチョウガニ属

Cancer イチョウガニの学名はリネー(Carl VON LINNÉ) の自然綱要の第 10 版 (Systema Naturae, ed 10)によって確立したが, リンネ以前にもこの学名は他の学者によって使われてい る。しかし、リネーの命名規約によって、リネーの 1758 年以前の学名はすべて無効になったも ので, Cancer が, 十脚類に与兄られた唯一の属名であったが, 後に, それが多くのかに類や異 尾類に分立していったのである。

日本産のイチョウガニ属は次の 6 種であるが, 最近アメリカ産のイチョウガニ, Cancer magister, Dana が食用に多量に輸入されているがその名前はまちまちである。日本の水産, 蟹, （全日本水産写真協会，昭和58年）ではこのかにをアメリカ同様にダンジネス蟹と呼んでいるが, 商店ではアメリカワタリガニと呼んでいる。1956 年にはこのカ二の生体が北海道釧路で阿部晃 治氏によって報告されている。この種が日本沿岸にまで移住しているのである。移住してきた 要因については，幼かにが船のバラストタンクによるものか自力によるものか不明である。

Cancer 属の日本産種類は次のとおりである。

Cancer gibbosulus (DE HAAH, 1835) イボイチョウガニ

C. japonicus ORTMANN, 1893 イチョウガニ

C. amphioetus RATHBUN, 1898 コイチョウガニ

C. tumifrons YoKoYA, 1933 ヒロハイチョウガニ

C. nadaensis SAKAI, 1969 ナダイチョウガニ

C. sakaii TAKEDA and MryAKE, 1972 ノウイチョウガニ

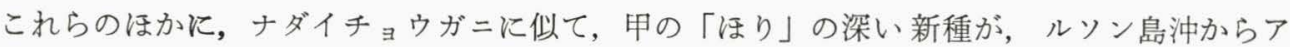


メリカの Proc. Biol. Washinton に記載中である, 即ち, C. luzonensis SAKAI である。

$$
\text { Cancer nadaensis SAKAI } 1969 \text { ナダイチョウガニ }
$$

(Pl. VI, Fig. D)

Cancer nadaensis SAKAI, 1969, p. 258, text-fig. 7.

検討標本 :

1 우, 抱卵, 大磯沖, 相模湾 1882 , 池田 等氏, 採集。

1 우 (幼), 葉山沖 1982 , 採集者, 池田 等氏，採集。

本種の模式標本は守で, 紀伊半島名田にて採集, ワシントンのスミソニアン研究所に保存さ れている。本標本の幼形は成長個体にくらべて甲面の顆粒多く, 後側縁の棘顆粒も多い。

$$
\text { まぽろしのかに, Cancer balssi SAKAIについて。 }
$$

種名だけがあって実在のないかにがある。

西ドイッのミュンヘンの Staats Sammlung の博物館に Heinrich BALSS という硯学の甲殻 類学者がいた。この学者が1922年に Platepistoma なるハワイ産の蟹の第二種の Platepistoma anaglyptum なる種類を三崎から記載した。そのかににノウイチョウガニなる和名を提供した が，そのかには Platepistoma ではなくCancer 属に入るべきで, アメリカの Cancer oregonensis に近い種類とした。そして 1965 年の相模湾蟹類の p. 105 に Cancer anaglyptum と改 めた。しかしこの書物の発行まぎわになって，その名前がその昔に，ヒヅメガニの旧名に使わ れたことがあることを見出し，命名規約によって同じ名前が二度使え防ことを知った。私はま に合わない故にこの名前は後に変更する旨を脚註につけて出版してしまった。

当時アメリカのロスアンゼルスの自然博物館に T. D. NATIONS という学者がいて, Cancer の化石から現存種までを研究していて，そのモノグラフを出版中であった。NATIONS 博士は相 模湾産蟹類の脚註を見て私に Cancer をどのように変更したのかと問い合せてきた。私は近く 出版する書物で BALSS 博士の名をとって Cancer balssi と変える積りと返答した。NATIONS 博士はそのようにモノグラフに書き入れていた。所がその時, 私の脚註を見て武田・三宅両氏 が 1972年の小論文の序文の中に Cancer とは関係のないのにこの種の学名を変更して Cancer sakaii として印刷してしまっていた。私はそれを見て NATIONS 博士に Cancer balssi を変兄 るように依頼した。幸なことにそれが間に合って, NATIONS 博士は Cancer balssi を直して sakaii とかえたが，残念なことに p. 68 の見事な甲殼の写真と鎉脚の図が名前と共に Cancer balssi SAKAI と残ってしまい一つの蟹に二つの名前がついてしまった。勿論 sakaii の方が残 ることになるが,一言電話でも手紙でも印刷前に連絡して貴えばこのような事は起こらなかっ たと思う。故 BALSS 博士にはまぼろしの名称を捧げてしまったことになってしまい申し訳な いと思っている。

Fam. Portunidae RAfINESQUE, 1815 わたりがに科

Caphyra minabensis New Species ミナペトサカガザミ

(Pl. V, Fig. B) 
検討標本：

1ㅇ, 完模式標本, 珊瑚類のユビノウトサカ (Microspicularia digitularia) に着生, 和歌 山県南部海岸, 著者採集, 3 月29日, 1973。

Caphyra 属の日本産の種類は,

Caphyra yookadai SAKAI, 1933

伊豆半島から紀州, オーストラリアから印度洋に分布。

C. rotundifrons A. Milne EDWARDS, 1869

八丈島,インドネシア, オーストラリア, 印度洋にかけて分布。

ここに、新種として上記 1 種を加える。本種は腔腸動物のユビノウトサカに雌雄で着生する ものと思われるが採集されたのは榫だけである。体全部が白色で色や斑紋はない。眼窩外歯の 1 棘が存在する点において H. LENZ が記載した東マダガスカルの Caphyra unidentata LENZ, 1910 に似ているがこの種類では眼窩外歯の後方の 1 棘の後方で, 前側縁は外に開かず, 甲尻に 強く狭まっている。本種では甲はその棘の後方で強く外方に開いて甚だしく甲幅がひろがって いる。額は不明瞭に 4 葉に分れ, 中央の切れこみはやや深い。甲面の前縁からの稜線は不明瞭 で，甲面は僅かにもり上っている。

鉗脚はやや強大で, その掌節は背面に縦の稜線が 2 条平行している。歩脚の指節はいずれる 鋭く尖って着生に役立っている。最後の 1 対の歩脚は背側に扁している。

大きさ：甲長 $6 \mathrm{~mm}$, 甲幅 $7 \mathrm{~mm}$

Charybdis (Charybdis) anisodon DE HAAN, 1833 ホンュンイシガニ

(Pl. I, Fig. 4)

Portunus anisodon De HAAN, 1833, p. 42.

Goniosoma anisodon A. Milne Edwards, 1861, p. 381, pl. 35, fig. 4.

Charybdis (Charybdis) anisodon LeEne, 1838, p. 64, fig. 29.

\section{検討標本:}

1今, 1우 〈いら川河口, 西表島, 沖繩。採集者, 吉川博信, 鹿児島大。

1\}, 1 ㅇ, 奄美大島, 吉川博信氏連絡。

本種はその記録された年代は古く印度洋が原産地になっていて分布は広く極東沿岸から 全印 度洋に互っているが不思議と日本沿岸での確実な産地は記録されていなかった。上記は確実な 記録である。本種は小形種で甲殸も胸脚も無毛で, 清浄な感じである。甲は横にひろく，甲面 の横条は胃域のものと側方第 5 歯からのものが明確で，他には稜線はない。

額の 6 歯はいずれも先端まるく, 中央の 2 歯は僅かに下面にある。前側縁の 6 歯のらち, 第 2 歯は小さく, 最後の第 6 歯は大きく, 側方に突出している。

鈷脚は長節の前縁に 2 大棘, 腕節は内端の 1 棘大きく, 外方下端の 1 棘は小さい。掌節は基 部に 1 棘, 上縁には末端に近く 1 棘があるのみである。腹部は雄では第 7 節が 末端にいくほど せまくなっている。歩脚はやさしく，指節は長い。 
大きさ：甲長 $26 \mathrm{~mm}$, 甲幅 $46 \mathrm{~mm}$ 。

分布: 極東の韓国, 日本, 台湾, ホンコン, タイ国, フィリッピン, シンガポールから印度 紅海, ケープタウンに至る。

Fam. Xanthidae MAcLEAY, 1838 おうぎがに科

$$
\text { Genus Actumnus DANA, } 1851 \text { イボテガニ属 }
$$

本属は印度・太平洋産の大属であるがケブカガニ属 (Pilumnus) から転入された種が多く反 対にこの属から他属に転出した種も多い。印度太平洋に 30 種余りも数えるが, 日本産として確 認できるのは次の 7 種位であろう。

Actumnus squamosus (DE HAAN, 1835) イボテガ=

A. setifer (DE HAAN, 1835) スエヒロイボテガニ

A. obessus (DANA, 1852) オベッサイボテガニ

A. forficigerus (STIMPSON, 1858) イボテガニモドキ

A. dorsipes (STIMPSON, 1858) セアシイボテガニ

A. intermedius BALss, 1922 ミゾイボテガニ

数あるActumnus の中から次の 1 種は沖繩・石垣島から採集されたもので，紀伊南部からも 同種が採集されている。共に体は軟毛でお拈われているが甲殸面に分割された小域は毛や溝の 間から観察できる。

Actumnus dorsipes (STINPSON, 1858) セアシイボテガニ

(Pl. VI, Fig. 2; Pl. VIIl, Fig. C)

Pilumnus dorsipes Stimpson, 1858, p. 37; 1907, p. 70, pl. 9, fig. 3.

Not-Pilumnus dorsipes Alcock, 1898, p. 197; Borradaile, 1902, p. 264 ; Rathbun, 1910, p. 356, pl. 1, figs. 3, $7=$ Pilumnus sinensis GoRDON, 1931.

Actumnus dorsipes SAKAI, 1939, p. 529, pl. 99, kg. 7; 1965, p. 156, pl. 76, fig. 5; 1976, p. 497, text-fig. 266.

検討標本 :

1今, 1, 吹通川, 石垣島, 沖繩, 大石正道採集, (筑波大学学生)

甲は純然たる Actumnus で, 歩脚は背に偏している。毛を除いた甲面の小域は各々が隆起し ており，磨滅した顆粒が散在していり。甲域のらち $1 \mathrm{M}$ は小さく $2 \mathrm{M}$ はそれぞれ外端で僅か に切れこんでいる外は完縁であり， $3 \mathrm{M}$ は中央で僅かに二分して先方でせまく，腸域は大きく て中央で二分している。前側縁の 4 歯は小顆粒でふらどられている。

甲の小域の分岐の状況は本州産の Actumnus dorsipes とほぼ同様であるが，その露出してい る状況は沖繩産の方が著しい。紀州南部産の種は雌雄共に沖繩産のものとほぼ同様である。

大きさ：甲長 $9 \mathrm{~mm}$, 甲幅 $13.5 \mathrm{~mm}$

分布: 相模湾, 紀伊半島, 長崎, 沖繩, ホンコン。 


\section{イボテガニ属 (Actumnus) に関係のある種属について}

1969年に武田・三宅は Actumnus 属の日本産について述べているが, 私の考觉によれば, 彼 等の種類のうち, 少くとも 4 種は Actumnus ではない, 別属であろら。

1. Actumnus elegans DE MAN, 1887 につい。

この種は1887年に, DE MAN によって Mergui Archipelago から記載されたが図は載って いない。後に Alcock はその種をしらべ Pilumnus scabriusculus WHITE に近い種類と考皇た が所属はもと通り Actumnus とした。

1933 年に H. Balss は亜科 Pilumniae の研究の中で新属 Globopilumnus を新設し, その Type に DANA, 1852年の Pilumnus globosus を置き, DE MAN の Actumnus elegans をこ れと同種にした。

しかし後に印度の CHOPRA and DAS は1937年に DE MAN の Paratype と Mergui Archiplago からの標本も共に較べて, DE MAN の Actumnus elegans は BALSS の Globopilumnus とは異なる種類で, 従って独立の種であることを確認した。しかしCHOPRA \& DAS の図から 判断すると elegans なる種類は前側縁の棘の状況と額及び眼窝上縁の状態から Actumnus のそ れとは異っていることは事実であろう。

武田・三宅は Actumnus elegans として, 有明海と福岡県沖/島から記載しているが, 彼等 の挿図から判断して, 甲面の額, 眼窩, 前側縁の平たい顆粒と密に配列した尖らない歯などから Actumnus にも Globospilumnus にも似ていない別属であろう。

2. Platypodia digitalis RATHBUn 1907 について

本種は M.J. RATHBUN によって1907年にタヒチ島から記載された種である。

Platypodia digitalis, Rathbun, 1907, p. 38, pl. 1, fig. 6; pl. 9, figs. 4, 4a.

Actumnus digitalis, Bouvier, 1968, p. 87; TAKeda \& Miyake, 1969, p. 101, text-fig. 4.

本種は原著者 RAThbUM は Platypodia（ヒラアシオウギガニ属）に入れたが，所属が Actumnus に近いといらのでイボテガ二属に入れた著者もあるが, 額, 眼窩縁, 特に前側縁の歯 は板状に縁どられており Actumnus ではあり得ない。ヒラアシオウギガニの類でも, 額や前側 縁の板状発達が弱く, はさみ脚の掌節や歩脚の腕節や長節に板状発達のない, 例兄ばヒメヒラ アシオウギガニのような種類も存在する。特に RATHBUM の原著の pl. 9, figs. 4, 4a には, 鉗脚の不動指の基部に近く大きい歯があって, Platypodia tomentosa や P. semigranosa と同 様な特徴を有している。

然しながら digitalis では令の腹部が 7 節にそれぞれ区別されるのに対しActumnus や Platypodia では 5 節即ち第 $3-5$ 節が癒合しているという両者のちがいがある。また digitalis の甲では側胃域が大きくて横に楕円形を呈している特殊な特徴があるのに対し他の属では側胃 域は縦に長く，二従裂しているのが通常である。

結論として digitalis なる種は Platypodia 属とActumnus 属の中間の性質をおびた別属と 考学らる。

大きさ：甲長 $8.4 \mathrm{~mm}$, 甲幅は $11.5 \mathrm{~mm}$ 。

分布: 沖繩, タヒチ, カロリン, モーリシァス等。 
3. Pilumnus marginatus STIMPSON, 1858 について

この種類は Stimpson によって沖繩から記載された種類である。そして完全な形の雄が画か れているが, その後これに該当する種類は再採集されていない。武田・三宅は 1969 年の記載で この種類を, 他の属に入れて, Pilumnopeus marginatus (STIMPSON) と記載しているが, それ は Stimpson の種と異なり, 甲幅も大きく，甲背面が長毛で和おわれ， marginatus のよらな Actumnus 類似の甲域の分割はなく，別種の蟹と思われる。

STIMPSON の原記載ではこの種類をPilumnus（ケブカガニ属）として扱っているが， H. Balss もケブカガニ巠科の研究の中で, このかにをやはりPilumnus 属として扱っている。

甲の幅もせまく甲域の分割は Actumnus に近く，乙かし胃域の中央の $3 \mathrm{M}$ の前方はせまく 中心部と離れていて異っている。前側縁の 5 歯の分割と顆粒に拈抒われた点はActumnus に似 ているが, 鈄脚の腕節掌節には顆粒や小棘がなく平滑である。歩脚も細くて, 甲の背面に偏す ることなく，細い。この種はActumnus に似ているが Pilumnus であろう。

STIMPSON の原標本はシカゴの大火災で焼失し残っていない, その原標本が沖繩のどこで採 集されたかの記録もない。

4. Actumnus similis TAKEDA \& MiYAKe, 1969

この種は日本産ではなく, パラウ島のものであるが甲の特徵や鉗脚の腕節・掌節の粒々の様 子からみて Actumnus 属ではなくParapilumnus 属あたりの蟹であるう。

\section{Genus Actaea DE HAAN, 1833 の分立}

Actaea 属は1833年に DE HAAN によってシーボルトの日本動物誌, 甲殼類篇に設立された 属で, サメハダオウギガニなる和名で親しまれてきた属である。その模式標本は Actaea granulata である。この属は大きな属であって極めて多数の種類が含まれていた。1925年にストッ クホルムの Dr. T. ODHNER が Actaea 属のモノグラフを著わし, 多数の種類を記載した。し かし今日そのモノグラフを検討してみると，中には Actaea 属でない他の属もたくさんに含ま れている。特に最近パリの自然博物館の D. GUINOT 博士の研究によって多数の属が Actaea から分立した。例光ば, Paractaea, Gaillardiellus, Novactaea, Forestia, Serenius などがそれ で，日本にもそれらの属はふくまれている。私は ODHNER の Actaea の中から二つの新属を 記載した，その一つは Lobiactaea で，新和名をミカドアワッブガニ， 天皇陛下が 1977年と 1978年の二回にわたり，伊豆下田の御用邸でご採集になったもので Odhner が1925年にただ一 度だけ南支那海からActaea 属として記載したもの。他の一つは ODHNER の名を冠したもの, 紀州から多く記載されているトゲオウギガニの仲間である。

\section{Lobiactaea ミカドアワッブガニ(新属)}

Type Species: Actaea lobipes OdHner, 1925

このかには1925年に ODHNER によって南支那海の Macclefleld 岩礁から記載されたがその 後一度もとれたことがなかった。所が 1977年12月と 1978年 1 月に天皇陛下が伊豆下田の御用邸 で御採集になり, 又 1978 年には伊豆海洋公園で永井誠二氏が 1 皇採集して南支那海と伊豆下 
田が正確な産地であることがわかった。

新属ミカドアワッブガニは, 甲殼の形態が Actaea 属に近いが甲面は胃域の $2 \mathrm{M}$ が U 字形 で $3 \mathrm{M}$ と腸域が平面である以外，他の小域はすべて小さく瘤起になっており，前側縁も 4 個の 瘤起となっており夫々が小顆粒と剛毛でおおわれている。歩脚も 針脚も夫々長節・腕節・掌節 が顆粒と剛毛でおおわれた瘤隆起でおおわれている。

Lobiactaea lobipes のほかには Actaea hieroglyphica ODHNER, 1925, Actaea boletaria RATHBUN, 1911 などの印度洋産の種類が新属に入るように思われる。

\section{Lobiactaea lobipes (ODHNER, 1925) ミカドアワッブガニ}

(P1. II, Fig. 2; Pl. VIII, Fig. B)

Actaea lobipes ODHner, 1925, p. 44, pl. 3, fig. 2, 2a.

Gaimardiellus lobipes SAKAI, 1980, p. 83.

検討標本 :

1今, 須崎, 伊豆下田御用邸, 天皇陛下御採集, 1972年12月。

1今, 伊豆下田, 爪木崎, 伊豆下田御用邸, 天皇陛下御採集, 1978年 1 月。

1§, 伊豆下田, マリンパーク, 永井誠二氏採集, 葉山池田等氏持参。

甲面は多くの小域に分割し, 各小域はすべて顆粒と剛毛に新拈われている。小域のらち, 胃 域の $2 \mathrm{M}$ はU 字形に分れ, $3 \mathrm{M}$ はほぼ平である。胃域の後方の $1 \mathrm{P}$ もきく平たいがその ほかの小域はすべて小瘤起にもれ上り各々が顆粒とまばらな剛毛にお敊われている。前側縁で は眼窝外棘は小さく，その後方の 4 歯は顆粒にお拉われた瘤状の突出となっている。

鉗脚も歩脚も長節, 腕節, 掌節がすべて上縁, 外面が顆粒と剛毛におおおれた小瘤起でおお われている。

雄の第一腹肢は先端がかぎ状にまがり頂に長毛が叢生している。

大ささ：甲長 $10 \mathrm{~mm}$ ，甲幅 $14.5 \mathrm{~mm}$ 。

分布：伊豆下田及び南支那海の Macclefield Bank。

Odhneria ハリトゲオウギガニ（新属）

Type Species: Odhneria acutidens New Species

甲殼が多くの小域に分れ, 各小域には大小の堆状の突起を生じていて, その瘤突起はふつう の Actaea 属のそれょり大形である。胃域・鰓域は小域に分れている。前側縁は眼窩外歯の後 方に 4 歯あり，各歯の頂のものはそれぞれ大きくて尖っている。鎮脚の腕節・掌節はいずれも 大きく太り，大小の顆粒が尖っていてまばらであり，小面には別れていない。紀伊南部産の Actaea echinus, 印度洋産の Actaea nodulosa などはこの新属に入る。(Gunot 1970, p. 204.)

Odhneria acutidens New Species ハリトゲオウギガニ(新属・新種)

(P1. II, Fig. 3; P1. VII, Fig. D) 


\section{検討標本：}

1今, male holotype, 熊野灘, 和歌山県; 水深 $50 \mathrm{~m}$, 採集者, 飯柴英次氏, 1972年。 甲殼は全面小域に分れ各小域は大小の尖った顆粒で抢扔われていて，各小域を分つ溝は深く てはっきりしている。胃域は中央の $3 \mathrm{M}$ の前端はせまく長く $3 \mathrm{M}$ の後方は二つに分れて独立 している。2 $\mathrm{M}$ は判然と左右二つずつに分れ $1 \mathrm{~F}$ む $1 \mathrm{M}$ あそれぞれ二つずつに分れて独立し ている。肝域, 鰓域はそれぞれ小域に分れ, 後側縁の顆粒は一面に生じた顆粒の斜前方に幅広 い溝があって大きい顆粒がそのへりに並んでいる。腸域は小さい顆粒で敷きつめられている。 前側縁は眼窩外歯は小さいが後方の 4 歯は鋭く，頂の顆粒は特に大きい。鉗脚の腕節・掌節は 肥大しているが，小面は分割されずに大きい棘と小さい棘がややまばらに存在している。

合第一腹肢は長く先端の内側に揃った毛を生じている。(pl. II, fig. 3)

\section{Odhneria echinus (ALCOCK, 1898) トゲサメハダオウギガニ}

\section{(P1. II, Fig. 1)}

Actaea echinus Alcock, 1898, p. 149; Illus Invest Crust, pl. 37, fig. 3; SAKAI, 1965, p. 40, pl. 6 , fig. 7 .

\section{検討標本：}

3今令, 2 우 우, 紀伊長島, 長島高校生徒, 1960 1970年

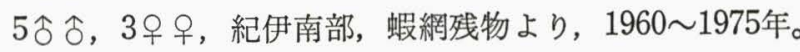

このカニは甲殻扣よび錙脚にある顆粒が前種にくらへてて大形で大顆粒は円錐形で尖っている。 甲面の溝も前種流ど目立たず, 構造もやや前種とは異っている。挿図で両者を比較できる。

甲長: $26 \mathrm{~mm}$, 甲幅 $38 \mathrm{~mm}$

分布：紀州沿岸及び印度マラペール海岸

GUINOT 博士も述べているように 》Actaea《margaritifera var. bullifera ALCOCK, 1898, $\gg$ Actaca《nodulosa なども Odhneria 属に入る。

\section{Genus Platypodia BELL, 1835 ヒラアシオウギガニ}

この属は1835年に BELLによって設立された属で, 故, BUITENDIJK によって1941年に再検討 され検索表も作られている(酒井，1976）。世界では17種程が日本からは 3 種が記録されていた が新たに 1 種が加兄られた。即ち, 全種としては,

Platypodia granulosa RUPPELL, 1830 ッブヒラアシオウギガニ, 所謂毒がにである。

P. semigranosa (HELLER, 1861) ヒメヒラアシオウギガニ

P. anaglypta (HELLER, 1861) ヒラアシオウギガニ

P. tomentosa (DE MAN, 1888) ケブカヒラアシオウギガニ, 日本でははじめてである。

\section{Platypodia tomentosa DE MAN, 1888 ケブカヒラアシオウギガニ}

(P1. II, Fig. 4 ; Pl. VIII, Figs. A, $\mathrm{A}_{1}$ ) 
Lophactaea semigranosa (Nec Heller) De MAN, 1888, p. 246, pl. VIII, fig. 46, Partim.

Lophactaea tomentosa DE MAM, 1902, p. 585.

Platypodia tomentosa, Buitendijk, 1941, p. 309, text-fig. 3c.

検討標本 :

$2 \hat{\jmath} \hat{0}, 3$ 우, 伊勢湾口, 和具。山下信夫氏蝦網から採集, 1981年 3 月。 全身顆粒におおわれ，顆粒の周辺には剛毛が多い。額と眼窩上縁は板状の縁でめぐらし，そ の上にまばらに顆粒を生ず。前側縁は連った板状の厚い縁でらちどられ，顆粒はない。甲域の らち $3 \mathrm{M}$ は前方にはのびず $2 \mathrm{M}$ は僅かに中央で 2 つ分れている, $1 \mathrm{M}$ は左右に顆粒が高く もれ上っていて厚い感がある。鉗脚の前節は上面にたての板状部が発達し, 歩脚は長節, 腕節, 前節にそれぞれ板状の縁が前縁に発達している。針脚の不動指は基部に近く大きい歯があって 先が 2,3 歯に分れている。指は両指共黒色である。この種は日本で初めてである。

甲長 $15 \mathrm{~mm}$, 甲幅 $21 \mathrm{~mm}$

分布：紀伊半島及び東部印度洋。

Platypodia semigranosa (HelleR, 1861) ヒメヒラアシオウギガニ

(Pl. VII, Figs. 5, B, $\mathrm{B}_{1}$.)

本種は既に著者の1976年の p. 405, pl. 144, fig. 3 亿原色の図が載せてあるが，その後又多 くの標本が 今, ○で得られたので甲殸の額から眼縁前側縁の特徵と雌雄共にある針脚不動指の 根元近くにある歯を図示する，その先端が浅く歯に分れている。

DE MAN の 1887, p. 216, pl. VIII, fig. 3, 3a の図は不動指の基部に, その特徵である大 型の歯のないことで Platypodia semigranulosa ではない, 別種である。

Genus Serenius GUINOT, 1976 クマノウモレオウギガニ属

この属名は前シンガポール国立博物館のニネスコ, スペシャリスト, 後のパリ自然科学博物 館員, 故, ラオール, 七レン博士 (Dr. Raoul SERÈNE) のために名つけケれたものである。命 名者はギノー (D. GUINOT) 博士である。 5 種をふくんでいるが, 日本産は 2 種でその中の一 種は日本ではじめてである。その 2 つ,

Serenius seylonicus (LAURIE, 1906 ヒメウモレオウギガニ

S. gemmula (DANA, 1852) クマノウモレオウギガニ

Serenius gemmula (DANA, 1852) クマノウモレオウギガニ

(P1. II, Fig. 5)

Zozymus gemmula DANA, 1852, p. 77; 1855, pl. 9, fig. 6 .

Zosymus gemmula, Guinot, 1967, p. 561; 1971, p. 1071.

Serenius gemmula, Guinot, 1976, p. 1976.

検討標本：

1今, 熊野灘沖, 採集者, 飯柴英次, トロール船による採集。 
この属はウモレオウギガニの Zosymus から派生した属で日本ではヒメウモレオウギガニ 1 種が知られていたのみである。

本種は甲が甲長よりも甲幅が大で，額と前側縁はひろく平板状に縁どられている。後者には 3 個の閉じた切れ込みがある。甲背は小域に分れ, 胃域・心域・肝域・鰓域はそれぞれ顆粒で 密に拈抒われている。後側縁の内側は一面に小顆粒でしきつめられている。

針脚は大きく, 腕節・掌節は上面・外面が大形の顆粒で敷きつめられている。歩脚は各対の 長節・腕節・前節が切れこみの入った広い板状の張り出しで縁どられ, 各節の上面は顆粒と粗 面で扮扔われている。

大きさ：甲長は $18 \mathrm{~mm}$, 甲幅は $26.5 \mathrm{~mm}$

分布：熊野灘及びインドネシア。

Nanocassiope granulipes (SAKAI, 1939) サガミヒメオウギガニ

(PI. III, Fig. 1; Pl. VII, Fig. C)

Heteropanope granulipes SAKAI, 1939, p. 546, text-fig. 59; SERÈne, 1964, p. 185, pl. 16, fig. A, text-fig. 1.

Micropanope granulipes, SAKaI, 1965, p. 139, pl. 70, fig. 2.

Nanocassiope granulipes, Guinot, 1967, p. 355; 1971, p. 1075; SAKAI, 1976, p. 433, pl. 156, fig. 1.

この小形の抢うぎがに類のかには熊野灘に極めて多く, 最も大きい標本で次のようである。 大きさ：甲長 $10 \mathrm{~mm}$, 甲幅 $16 \mathrm{~mm}$

分布：相模湾, 熊野灘, 東支那海, 南アフリカ沿岸。

Fam. Goneplacidae MacLeay, 1838 えんこうがに科

Beuroisia major (SAKAI, 1978) オオノコギリエンコウガニ

(口絵, Fig. 1)

Neopilumnoplax major SAKAI, 1978, p. 8, pl. II, fig. A, text-figs. 16, 16a, 17.

Beuroisia major Guinot \& B. Richer DE Forges, 1980, p. 244, pl. IV, figs. 4, 5, 5a.

この属は Neopilumnoplax 属から派生したもので, Beuroisia major のほかに Beuroisia dehameli forma dehameli, Beuroisia dehameli tomentosa 及び Beuroisia manquenei の 3 種 が GUINOT \& B. RICHER DE FORGES によって1980年に記録されている。

本種は中部太平洋の欽明海山で採集されると殆んど同時に相模湾で, 真鶴沖から1今が採集 され, つづいて大磯沖から 1今, 19が採集され, 又ついで伊勢湾口, 和具のちびき網で1981年 に1〕が採集されている。相模湾の採集者は池田等氏, 伊勢湾の採集者は山下信夫氏である。

Intesius pilosus GUINOT \& B. RICHER DE FORGES, 1980

$$
\text { ヒメノコギリェンコウガニ }
$$

(口絵 Fig. 2) 
この種の原産地は中部太平洋のニューカレドニアの東, Loyante 島の近くで, 採集者 ANDRE INTES 氏の名前を冠したものである。和具での採集は二回目のものである。色彩は黄赤色で全 面に毛を生じている。但し雄の大銈脚は無毛である。甲殼は額, 眼縁, 前側縁, 共に毛と共に 小顆粒が並んでいる。額は中央で僅かに切れこみ, 前側縁は 5 個の歯に分かれ第三・第四の歯 は大きい。甲殼の面は胃域・心域・腸域が明らかに分離し, 側方の胃域 (2M), 肝域, 前後の 鰓域が細分している, これら小域は毛でお拈われている。

銈脚は雄では一方が強大で, 毛を欠き, 小鉗脚は雌の鉗脚共々にやさしく, 且つ毛を以てお 抒われている。不動指・可動指共に根元から黒色で, 指の截面には $4 \sim 5$ 個の先の鈍い歯を有 している。

今の第一腹肢は太くて先端に近く小突起を生じている。

大きさ：甲長 $35.2 \mathrm{~mm}$, 甲幅 $42.0 \mathrm{~mm}$

分布: ニューカレドニアの東方と伊勢湾和具。

Fam. Pinnotheridae De HaAn, 1833 かくれがに科

Genus Sakaina SERÉnE, 1964 まめがにだまし属

Type Species: Sakaina japonica SERÉne, 1984

本属は故 R. Serene によって設立された属で, 今日までに 5 種をらくんでいる。即ち,

Sakaina yokoyai (GLASSELL, 1933) ヨコヤマメガニダマシ

S. asiatica (SAKAI, 1933) マメガニダマシ

S. japonica SERÈNE, 1964 ニホンマメガニダマシ

S. incisa SAKAI, 1969 ヤハズマメガニダマシ

S. koreensis KIM \& SAKAI, 1970 カンュクマメガニダマシ

以上 5 種のうち, ニホンマメガニダマシが相模湾以外の産地として熊野灘から採集された。 Text-fig. 21 にこれを示す。

\section{Sakaina japonica (SERÈNE, 1964) ニホンマメガニダマシ}

(Pl. VI, Fig. A)

Sakaina japonica SerÈne, 1964, p. 273, pl. 24, fig. B, text-fig. 22; SAKAI, 1965, p. 180, pl. 88, fig. $3 ; 1976$, pl. 201, fig. 2, text-fig. 319 .

検討標本 :

$1 \hat{0}$, 熊野灘浅所。

マメガニダマシの 5 種は日本産 4 種, 韓国産 1 種である。甲幅の最も大きいものがカンコク マメガニダマシ, 甲幅の最も小さいのがアジアマメガニダマシ, 甲殸が後方に強く狭っている のがヨコヤマメガニダマシ, 雄の腹部第 7 節が中央で喰い込んでいるのが, S. incisa である。

大きさ：甲長 $4.1 \mathrm{~mm}$, 甲幅 $7.0 \mathrm{~mm}$

分布: 相模湾, 紀伊半島。 
Fam. Ocypodidae RAFINESQUE, 1815 すながに科

Subfam. Camptandriinae, 1858 むつはありあけがに亜科

この亜科の中の属は四属で MANNING \& L.B. HOLTHUIS の研究による。

Camptandrium STIMPSON, 1858 ムッハアリアケガニ属

Cleistostoma DE HAAN, 1833 アリアケガニ属

Dairatonotns MANNING \& HolTHUIS, 1981 カワスナガニ属

Leipocten KEMP, 1915 カワリアリアケガニ属

以上の 4 属はいずれる日本産に含まれている。

\section{Camptandrium sp. ヤエヤマアリアケガニ}

(P1. VI, Fig. C)

本種は雌の幼形で，西表島のくいら川河口のマングローヴで採集されたが，種を決定するに は雄の腹部と雄の第一腹肢の形態を知らなければならず，そのため種の決定を今後に俟たなけ ればならない。

この属には近似種として Camptandrium sexdentatum があり, その他 C. elongatum Rathbun, 1929; C. starmuehlneri Pretzman, 1968; C. ambonensis Serène \& Moosa, 1971; and C. rathbuni TAKEDA, 1971 があり, いずれも西表島の標本に近い甲殼を有している。 $1 \mathrm{~mm}$ のメッシュのふるいでふるいとられた標本は幼形であるが 日本最初の属であり, 採集者 は鹿児島大学, 吉川信博氏 Oct. 1980, その成熟した合の採集されるのを待っている。

大きさ：甲長 $3.3 \mathrm{~mm}$, 甲幅 $3.4 \mathrm{~mm}$ 。

Genus Deiratonotus Manning \& Holthuis, 1981 カワスナガニ属

この属は Dr. MANNING 及び Dr. HolTHUIS によって創設されたもので雄の腹部が第 6 節 でくびれ，同の第一腹肢が強く根元にまで曲って尖り，毛は僅かである。学名は両氏によれば Deirato (稜の意) notus 背の意, 2 種だけがこれに該当し,

Deiratonotus cristatum (DE MAN, 1895) アリアケモドキ,

(前名 Paracleistostoma cristatum DE MAN)

D. japonicum (SAKAI, 1934) カワスナガニ,

(前名 Paracleistostoma japonicum SAKAI, 1934)

前者は日本, 韓国, 中国, 後者は日本にのみ知られている。これに第三番目の新種が 発見さ れた。即わち,

Deiratonotus tondensis New Species トンダカワスナガニ

(Pl. VIII, Figs. D, $\mathrm{D}_{1}, \mathrm{D}_{2}$ )

検討標本:

$2 \hat{\delta} \hat{\delta}, 3$ 우 우, 紀州富田川河口, 採集者, 神奈川博物館の村岡健作氏。 
ごく小形のかにで，カワスナガニと同じ環境に棲み淡水性である。甲は平たく，前方に広く， 額は横に真すぐで前側縁は不明瞭に丸みのある 3 歯に分れているが個体によっては 2 歯である。 甲面は属の名に反して横の筋はなく, 甲域は胃域・心域が区別でさ顆粒はない。口部は第三顎 脚の長節・坐節が頗る幅広く, そのために口廓は完全に閉ざされている。

鈷脚は今では肥大していて, 両指節の先端はスプーン形になっていて先端に毛を生じ, 泥土 を掬いその中の有機分を食するに適す。方では指節の基部に近く 1 歯を有し 歩脚は第 $2-4$ 対の長節の後縁と第 3 対, 第 4 対の腕節, 前節の表面に軟毛を密生している。

腹部は含では第 1 , 第 2 節は幅は広いが長さは極めて 短かく第 3 , 第 4 節は合一し, 第 5 節 の基部で特有のくびれを生じている。今の第一腹肢は基部にまで強く曲っていて, とがり, 毛 は少ない(Pl. VIII, $\mathrm{D}_{2}$ 図)。

大きさ：模式標本では甲長 $8.5 \mathrm{~mm}$, 甲幅 $11 \mathrm{~mm}$ 。今のところ紀州富田川で採集されたのみ である。

\section{Family Grapsidae MACLEAY, 1838 いわがに科 \\ Genus Iliograpsus BARNARD, 1955 チゴイワガニ属（新称）}

Camptandrium paludicola RATHBUN, 1909, 1910

Iliograpsus BARNARd 1955; CROSNIER 1965, p. 31

このかには1909年に Mary RATHBUN によってムッハアリアケガ二属の1種としてCamptandrium paludicola なる種名でタイ国から報告された。その後長い期間, 再記録されることなく 年月が過ぎたが, 45 年程たって南阿のバーナードによって, この属が Camptandrium ではな く, Iliograpsus と改められ, 今一つの新種 I. rhizophora が加觉られた (1955)。

然し1965年にパリのクロニエー (CROSNIER) 博士によってこの属が再検討され，この種が， いわがに科のオキナガレガニに近く置かれ，バーナードの種はラスバンの種のシノニムとされ た。そのため Iliograpsus はただ 1 種 I. paludicola だけが含まれていた。この属に第二の新 種が西表島から記録された。

\section{Iliograpsus nodulosus New Species チゴイワガニ(新種)}

(Pl. VI, Fig. E)

\section{Material examind :}

$1 \hat{0}, 1$ 우, both are immature; 鹿児島大学, 吉川信博氏採集。

日本でははじめてのこの属が西表のくいら川のマングローブから採集されたが雌雄ともに幼 形で, 鉗脚も歩脚も共に失われている。甲殻は僅かに $2 \times 3$ ミリという大きさであるが, 図に 示したように稜線や隆起が発達していて I. paludicola とは明らかに異っている。そのため本 種はIliograpsus の第 2 の新種と定めチゴイワガニなる新和名を提供した。錙脚や歩脚の整っ た成長形の標本がとれることを期待する。新種の特徴は次の通りである。

甲は額が中央で深くくぼんで二葉に分かれて拉り, その真後で稜線が 左右 1 対あり, それぞ れは外方で眼窩の前縁にまで曲っている。その後方にまた左右 1 本ずつの稜線と隆起とが対を なしている。甲殼の中央部では, 胃域が左右と後方でそれぞれ区切られている。心域は左右二 
つの小隆起に分れ，腸域は中央で小隆起となっている。

前鰓域には 1 個ずつのふくらみがあり，後鰓域には左右連った 2 個の隆起，そしてその外側 に斜の短かい稜線がある。後側縁と後縁には甲の縁に平行して, 断続の小稜線が走っている。

眼窩縁には切れ込みはなく, 眼窝外歯は鋭くて大きく, 前側縁の第 2 歯は低くて 鈍く第 3 歯 は最も大きくて鋭く, 第 4 歯は小さい。前側縁の崡の様子は RATHBUM の種と同じである。 大きさ：甲長 (우) は $3.9 \mathrm{~mm}$, 甲幅 $4.5 \mathrm{~mm}$

Genus Metopograpsus A.M. EDWARdS, 1853 ハシリイワガニ属 本属は印度太平洋から 17 種程が記録され，本邦からは3種，らち1種が新記載である。即わち， Metopograpsus messor (FORSKÅL, 1775)

M. thukuhar (OWEN, 1839)

M. latifrons (WHITE, 1847)

Metopograpsus latifrons (WHITE, 1847) クイラハシリイワガニ（新称）

(Pl. III, Fig. 2)

Grapsus latifrons White, 1847, Jukes' Voy. "Fly" V. 2, p. 337, pl. 2, fig. 2.

Metopograpsus pictus A. M. EDwARDS, 1873, p. 289, pl. 13, fig. 2.

Metopograpsus latifroes Tesch, 1918, p. 81; S. K. BAnERJEe 1960, p. 176, figs. 4j, 5d, 6a; SAKAI, 1980, p. 178.

検討標本 :

1今， 1ㅇ, くいら川マングローブ, 西表島, 鹿児島大学, 吉川信博氏採集。

本種は体がすべらかで, 前方に広く後方に強く狭まり, 前側縁には眼窝外歯の後方に歯がな w。

大きさ：甲長は $25 \mathrm{~mm}$ ，甲幅は $30 \mathrm{~mm}$

分布：印度ネシア, 印度洋各地, 西表からは日本最初。

\section{Neoeriocheir New Genus ヒメモクズガニ(新属)}

Type Species: Eriocheir leptognathus Rathbun, 1913

本種は中国北部, 韓国の黄海沿岸の産であるが日本では佐賀市の河口に豊産していることが 解った, その採集者は横浜市の管野徹氏と長崎市の松尾美好氏である。その豊富な, 且つ游泳 の生態から Eriocheir 属ではなく新属と改めたのである。旧 Eriocheir モクズガニ属は次の 3 種をふくむ。

1. Eriocheir japonicus DE HAAN, 1835 モクズガニ。日本全土, 㮖太, 沿海洲, 韓国の日 本海沿岸と黄海の日本寄り, 更に沖繩, 小笠原, 台湾, ホンコン迄。

2. Eriocheir sinensis H.M. EDWARDS 1853 シナモクズガニ。中国全土, 朝鮮の黄海治岸, 更に移住して北欧全土（1913年以後）

3. Eriocheir rectus SIMPSON, 1858 ミナミモクズガニ。マカオ, 台湾, 更に南沖繩 (八重 
山列島)。

Eriocheir rectus STINPSON, W. STINSON により1858に記載されたが, そのタイプはシカゴ の大火災で失われてしまった。しかし幸にして STINPSON の記録は残り，Rathbun によって 1907年に公刊された。それによると E. rectus は, 日本のモクズガニに似ていて額もまっすぐ で, はさみの前節には外面に毛が密生 (hand with a thick tuft of hair on outer surpace) とある。筆者 (1939) の写真は正しく E. rectus で, C. J. SHEN (1932) の E. rectus は本新 属をあらわした誤りである。

$$
\text { Neoeriocheir ヒメモクズガニ, 新属 }
$$

この新属は従来の Erioeir leptognathus RATHBUN, 1913 を独立させたもので, Eriocheir と は著しく異っているからである。その文献は,

Eriocheir leptognathus RathBun, 1913, p. 353, pl. 33, figs. 2, 3; KeMP 1918, p. 232 ; Tesch, 1918, p. 107; Balss, 1922, p. 152; Urita, 1926, p. 433; SAKAI, 1935, p. 6; Panning, 1938, p. 106; Kamita, 1938, p. 338, figs. 3; SAKAI, 1939, p. 671, pl. CIX, fig. 2 ; 1976 , p. 649 , fig. 356 .

Utica sinensis PARISI, 1918, p. 102, text-figs. 3a-d, pl. VIII, fig. 1.

Eriocheir rectus SHEn, 1932 (Nec StINPSON), p. 178, Text-figs. 111-113, pl. VII, fig. 6. 検討標本 :

1令, 塩田川, 佐賀県, 管野 徹氏採集, 1980。

$10 \hat{\jmath} \hat{0}, 8$ 우 우, 塩田川河口, 長崎, 松尾美好氏採集。

体は通常のモクズガニのようにかたくなく，うすくて平滑である。額はまっすぐで歯をなさ ず, 前側縁は左右平行し第 1 歯だけが長くて内方強く向っている。モクズガニの第四歯の位 置は歯をなさず，ただ小顆粒の線だけが甲の後側面に菱形の小面を区切っている。全甲面は平 滑であるが中央面から前方で横に隆起している。

針脚の掌節は外面に何ら毛を生ずることなく平滑で内面にだけ軟毛が密生していてその毛は 一部指部にまで及んでいる。歩脚はすべてやさしく, 各対では前縁と後縁に平行して長毛の列 を有し, 第 $1-3$ 対では腕節・前節・指節の各表面に平行して長毛の列を有す。やの第 1 腹肢 はモクズガニのそれに似ているがよりやさしい。

SHEN の Eriocheir rectus, PARISI の Utica sinensis は共にヒメモクズガニに属する。 
Explanations of Plates

I-VIH 


\section{Explanation of Plate I}

Fig. 1. Paraentomonyx depressus (SAKAI, New Genus). $\times 2$

Fig. 2. Petalomera acutidens New Species. $\times 1.5$

Fig. 3. Parthenope (Platylambrus) praedator (DE MAN, 1907). $\times 2$

Fig. 4. Charybdis (Charybdis) anisodon DE HAAN, 1833. $\times 1$ 
Plate I

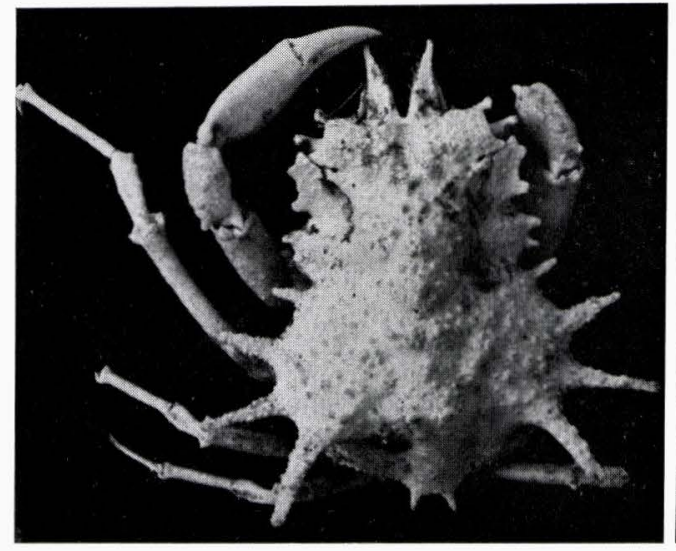

1

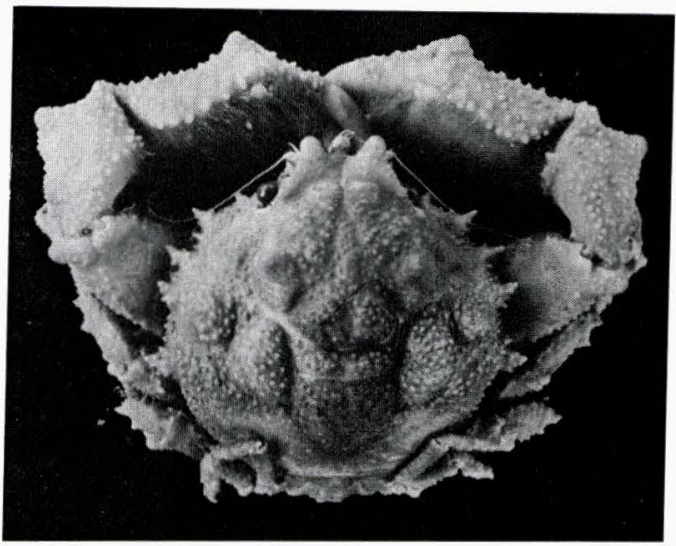

2

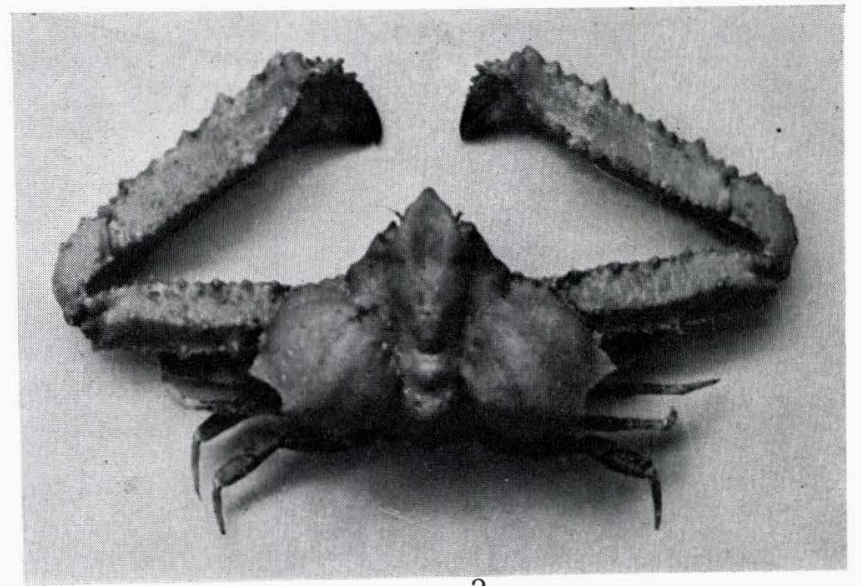

3

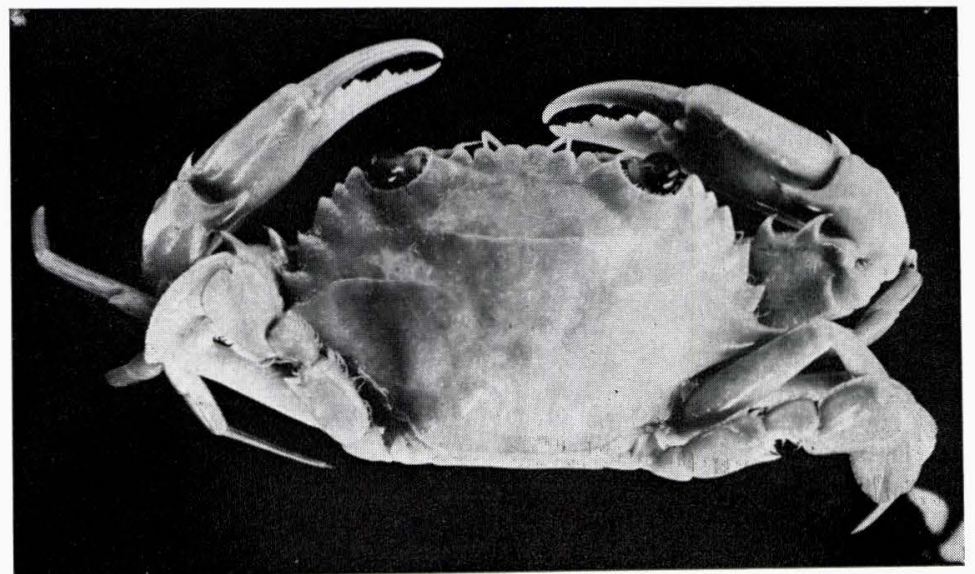

4 


\section{Explanation of Plate II}

Fig. 1. Odhneria ecninus (Alcock, 1898). $\times 1.2$

Fig. 2. Lobiactaea (New Tenus) lobipes (ODHNER, 1925). $\times 2.5$

Fig. 3. Odhneria acutidens New Genus and species. $\times 2.5$

Fig. 4. Platypodia tomentosa (DE MAN, 1902). $\times 2$

Fig. 5. Serenius gemmula (DANA, 1852). $\times 2$ 


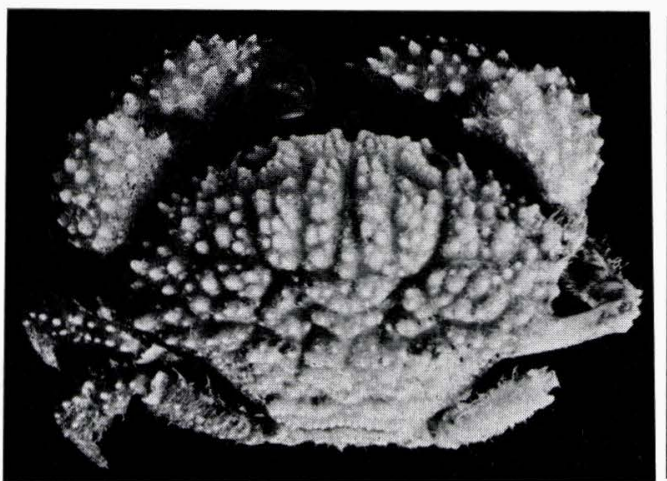

1

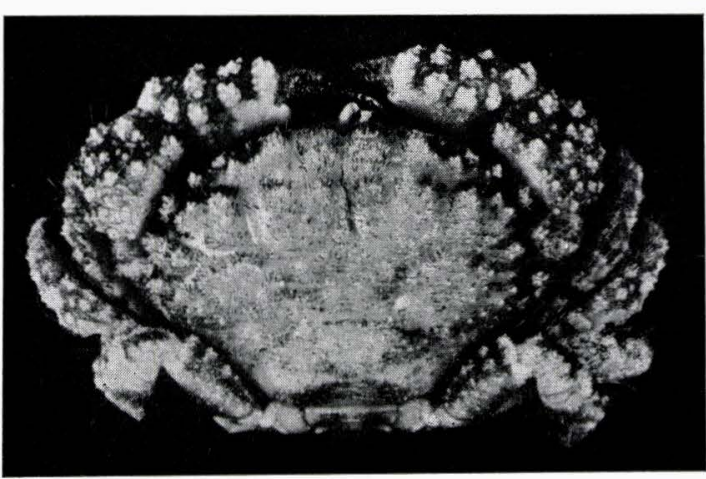

2

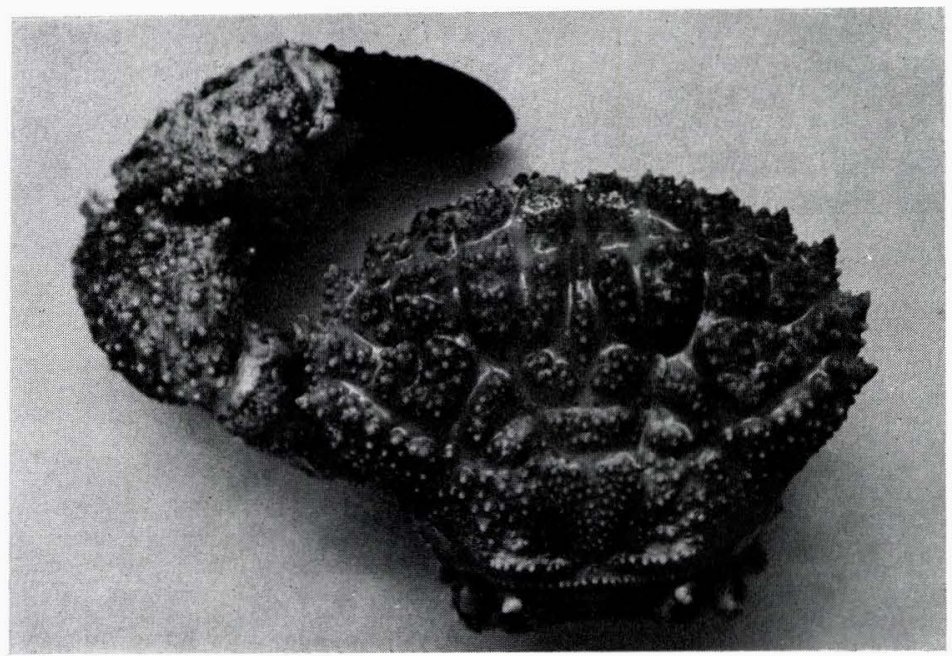

3
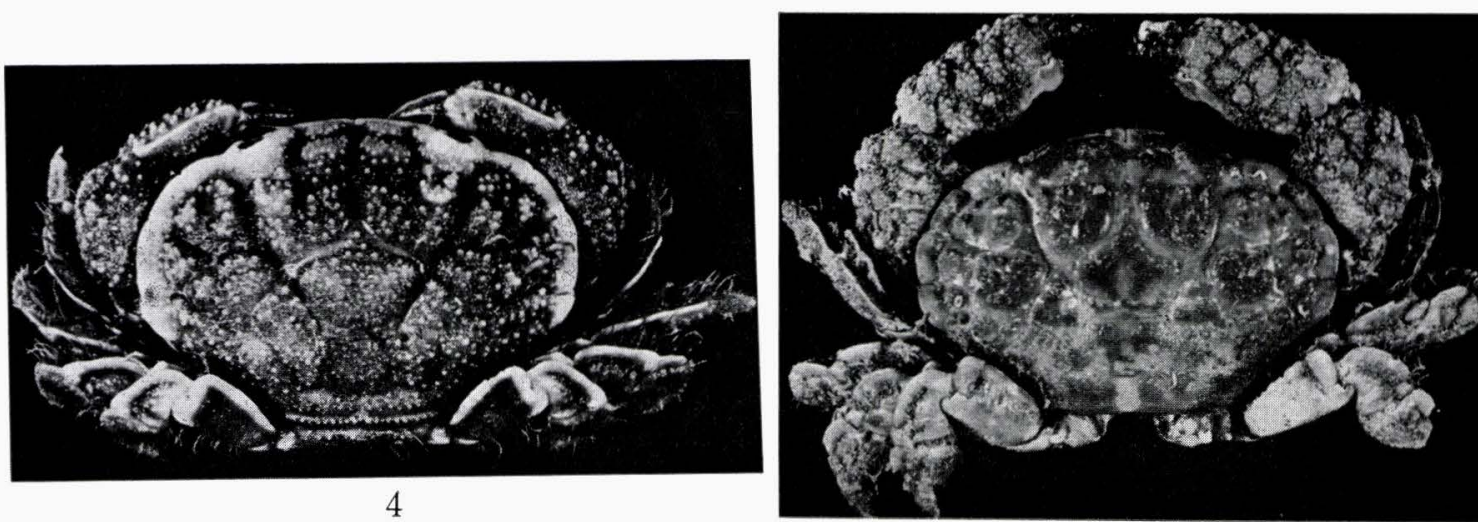

4 


\section{Explanation of ${ }_{2}^{2}$ Plate III}

Fig. 1. Nanocassiope granulipes (SAKAI, 1939). $\times 3$

Fig. 2. Metopograpsus latifrons (White, 1847). $\times 1.5$

Fig. 3. Neoeriocheir leptognathus (RATHbun, 1913). $\times 1.5$ 
Plate III
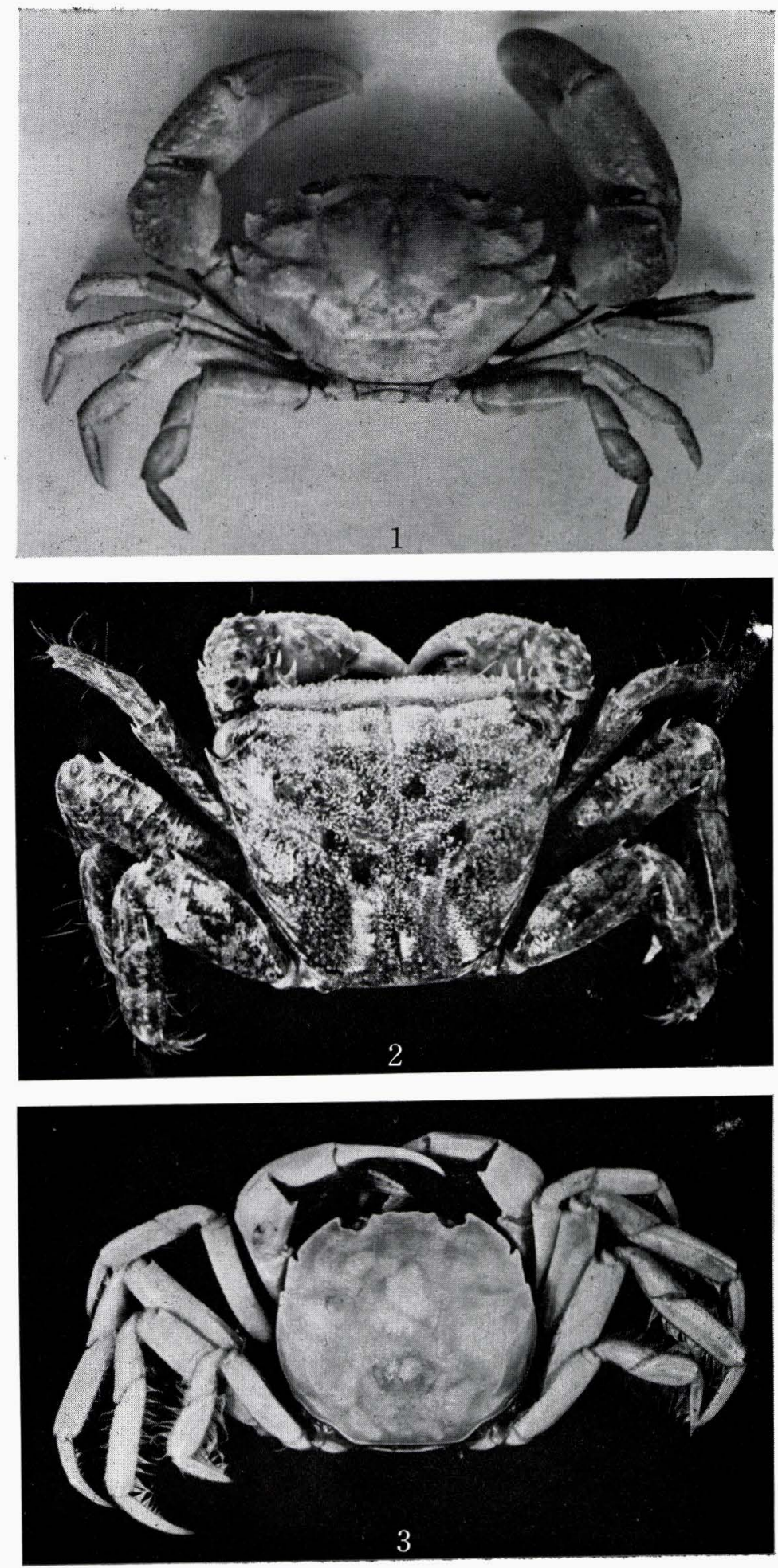


\section{Explanation of Plate IV}
A. Ethusa gracilipes Miers, 1886. $\times 2.9$
B. Praebebalia longidactyla Yokoy A, 1933. $\times 6$
C. Praebebalia kumanoensis New Species. $\times 6$ 
Plate IV
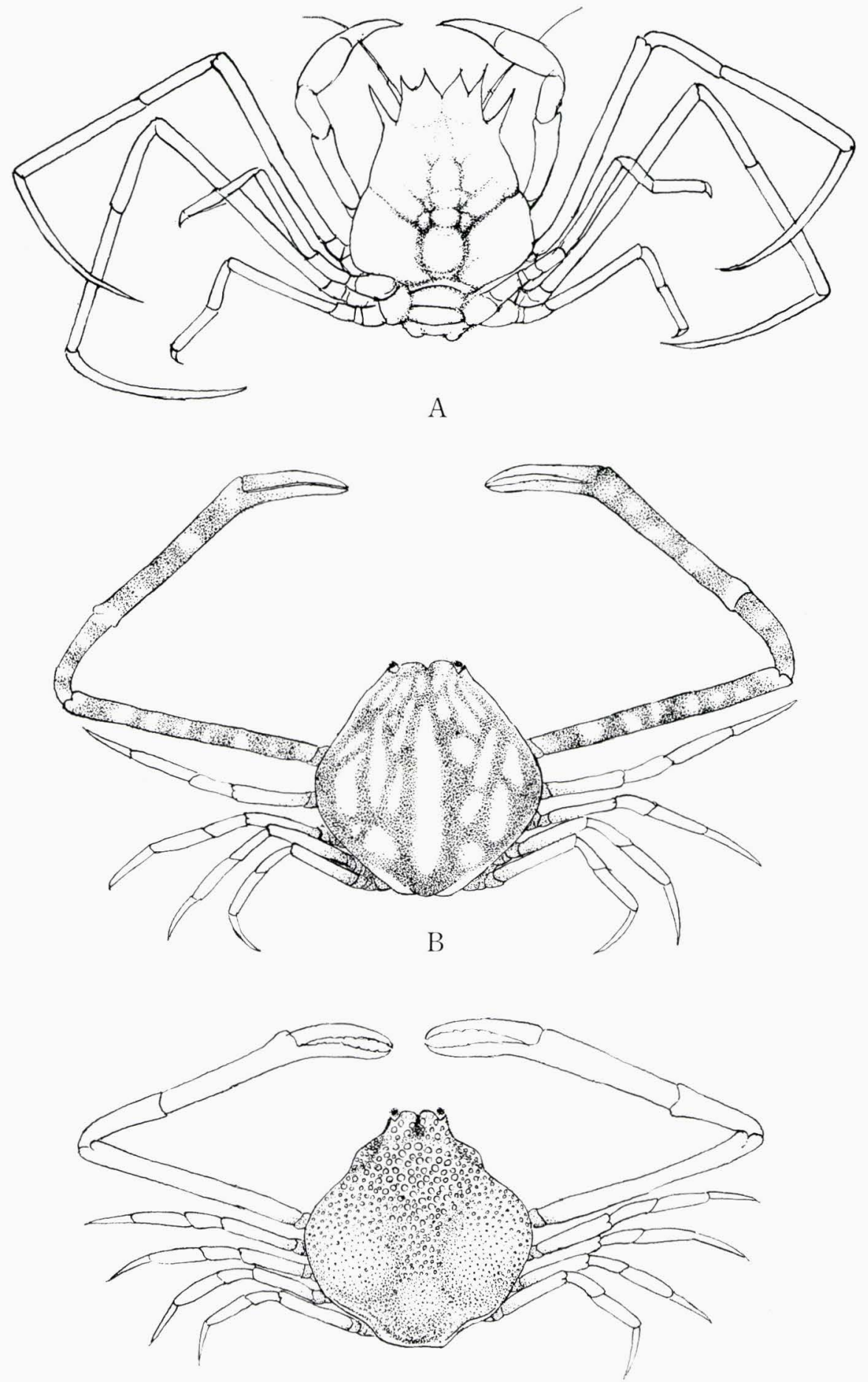

C 


\section{Explanation of Plate V}

A. Cryptodromia mariae IHLE, 1913. $\times 2.5$

B. Caphyra minabensis New Species. $\times 2.5$

C. Philyra iriomotensis New Species, $\times 9$

$\mathrm{C}_{1}$. Same, male anterior pleopod, $\times 34$,

$\mathrm{C}_{2}$. Same, strongly enlarged;

$\mathrm{C}_{3}$. Same, male abdomen, $\times 85$,

D. Paraentomonyx (New Genus) depressus, $\times 1.5$,

$\mathrm{D}_{1}$. Same, male anterior pleopod, $\times 35$. 

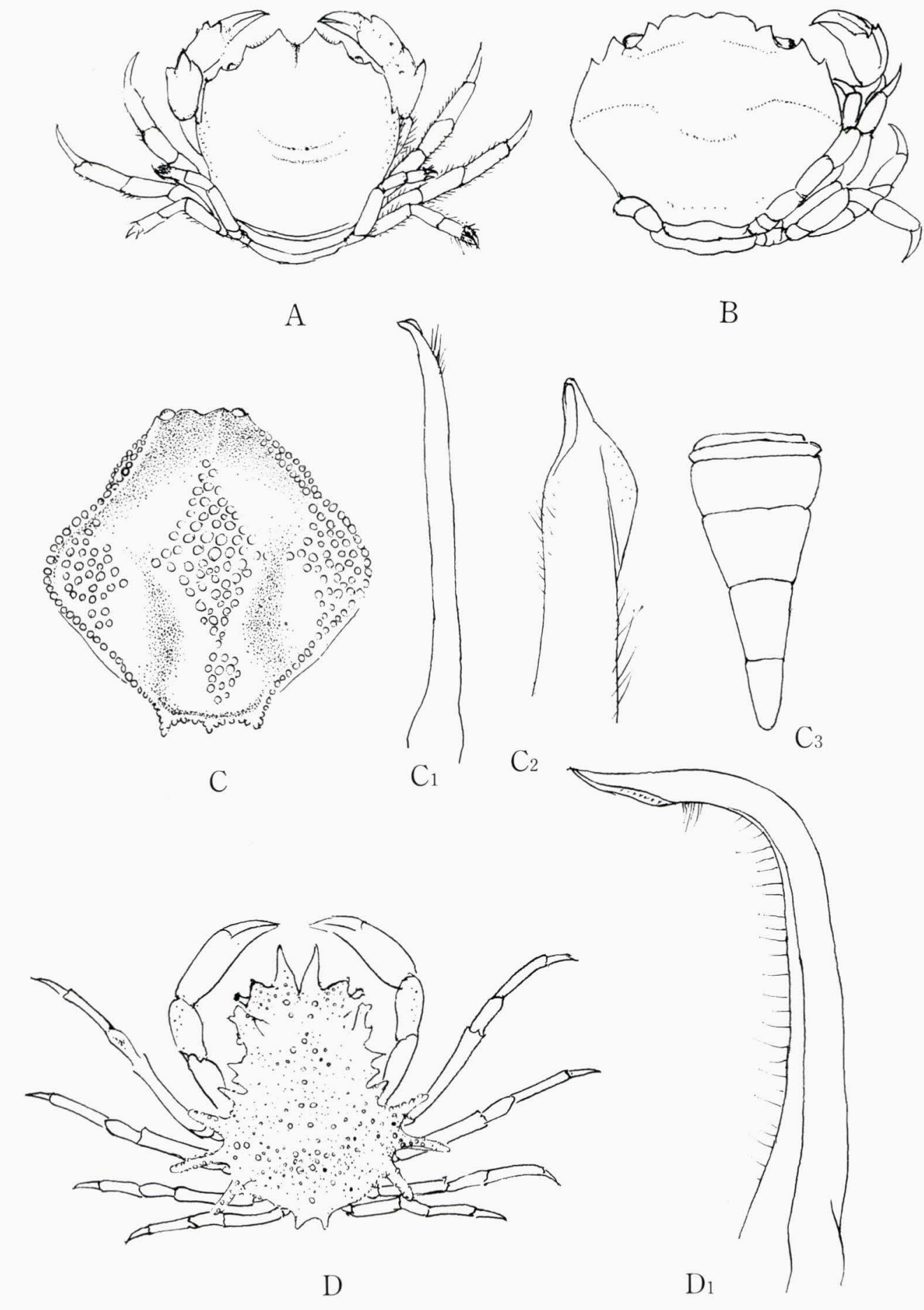

B 


\section{Explanation of Plate VI}
A. Sakaina japonica Serène, 1964. $\times 10$
B. Actumnus dorsipes (Stimpson, 1858). $\times 3$
C. Camptandrium sp. $\times 9$
D. Cancer nadaensis, Juv. $\times 2$
E. Iliograpsus nodulosus New Species. $\times 9$ 
Plate VI
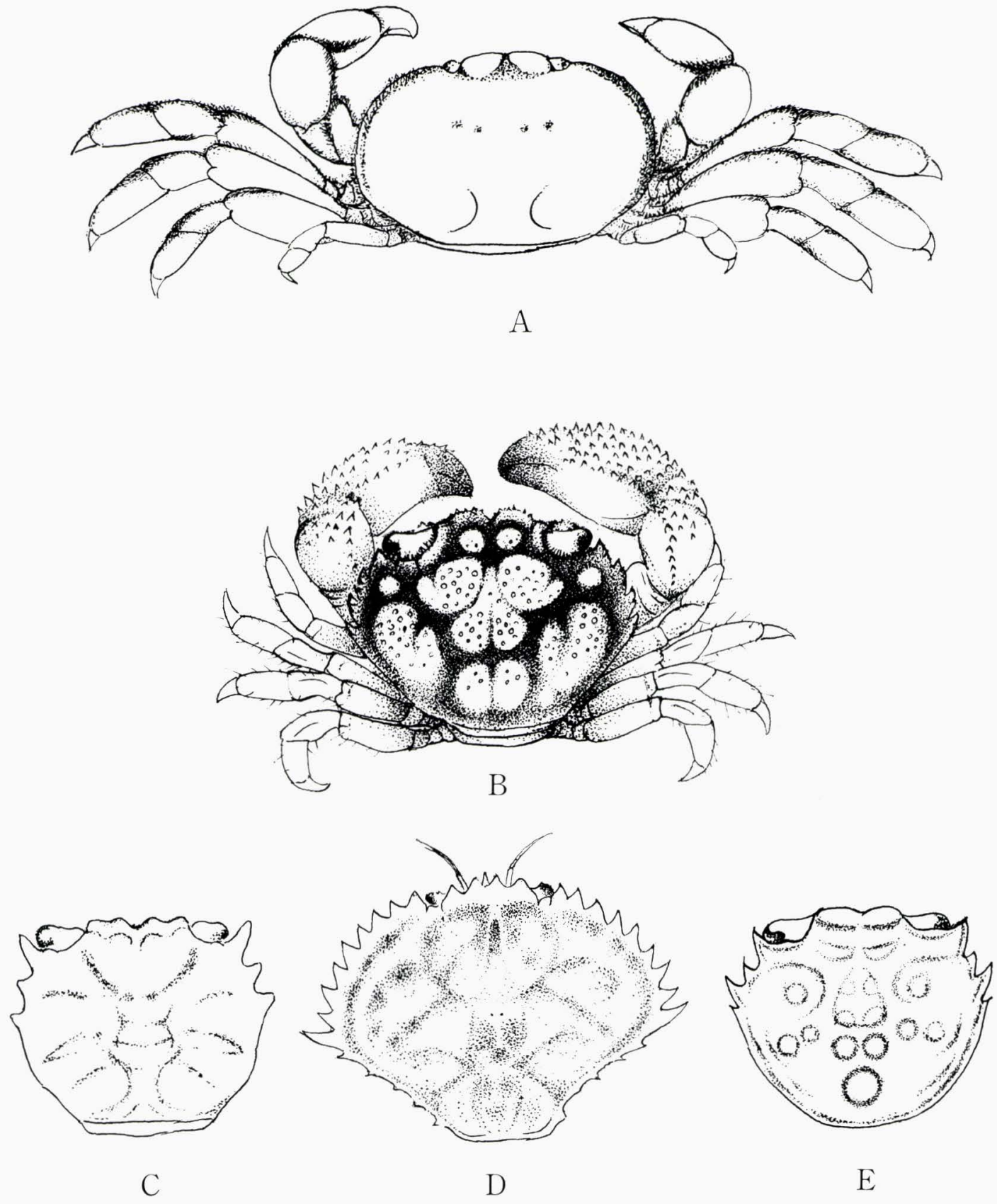


\section{Explanation of Plate VII}
A. Platypodia tomentosa (DE MAN,1882), a part of carapace. $\times 2.8$ $\mathrm{A}_{1}$. Chela of same. $\times 4$
B. Platypodia semigranosa (Heller, 1861). A part of carapace. $\times 2.8$ $B_{1}$. Chela of same $\times 4$
C. Anterior male pleopod of Nanocassiope granulipes, $\times 75$
D. Anterior male pleopod of Odneria acutidens, New Genus and species. $\times 75$
E. Anterior male pleopod of Ethusina gracilipes MIERS, 1886. ×75 
Plate VII
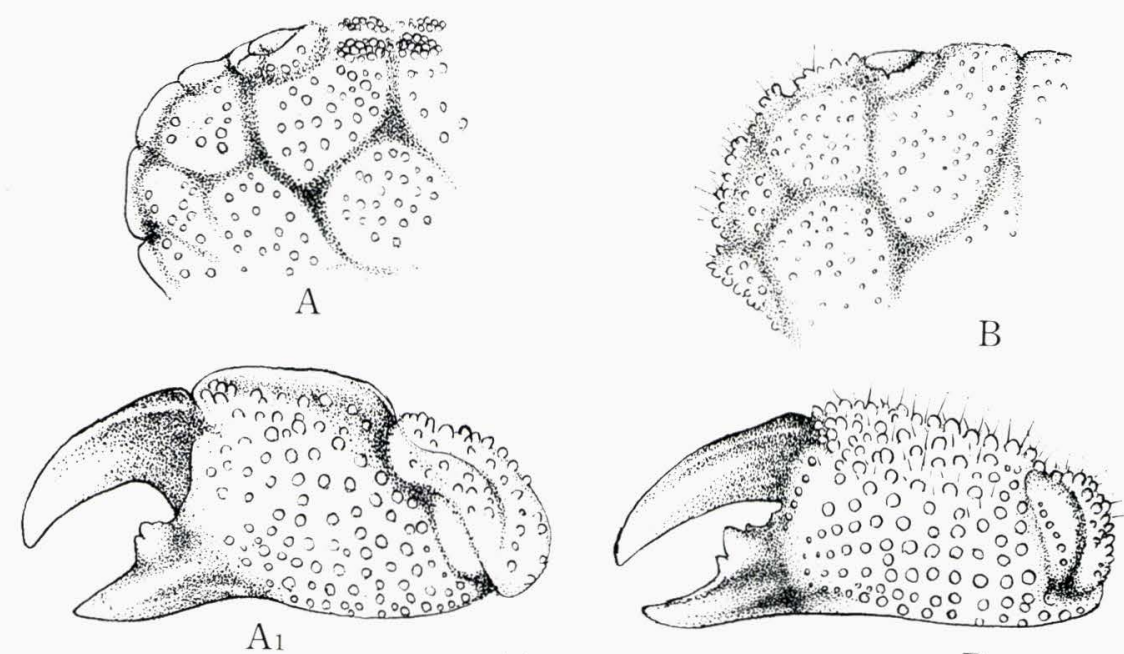

$\mathrm{B}_{1}$
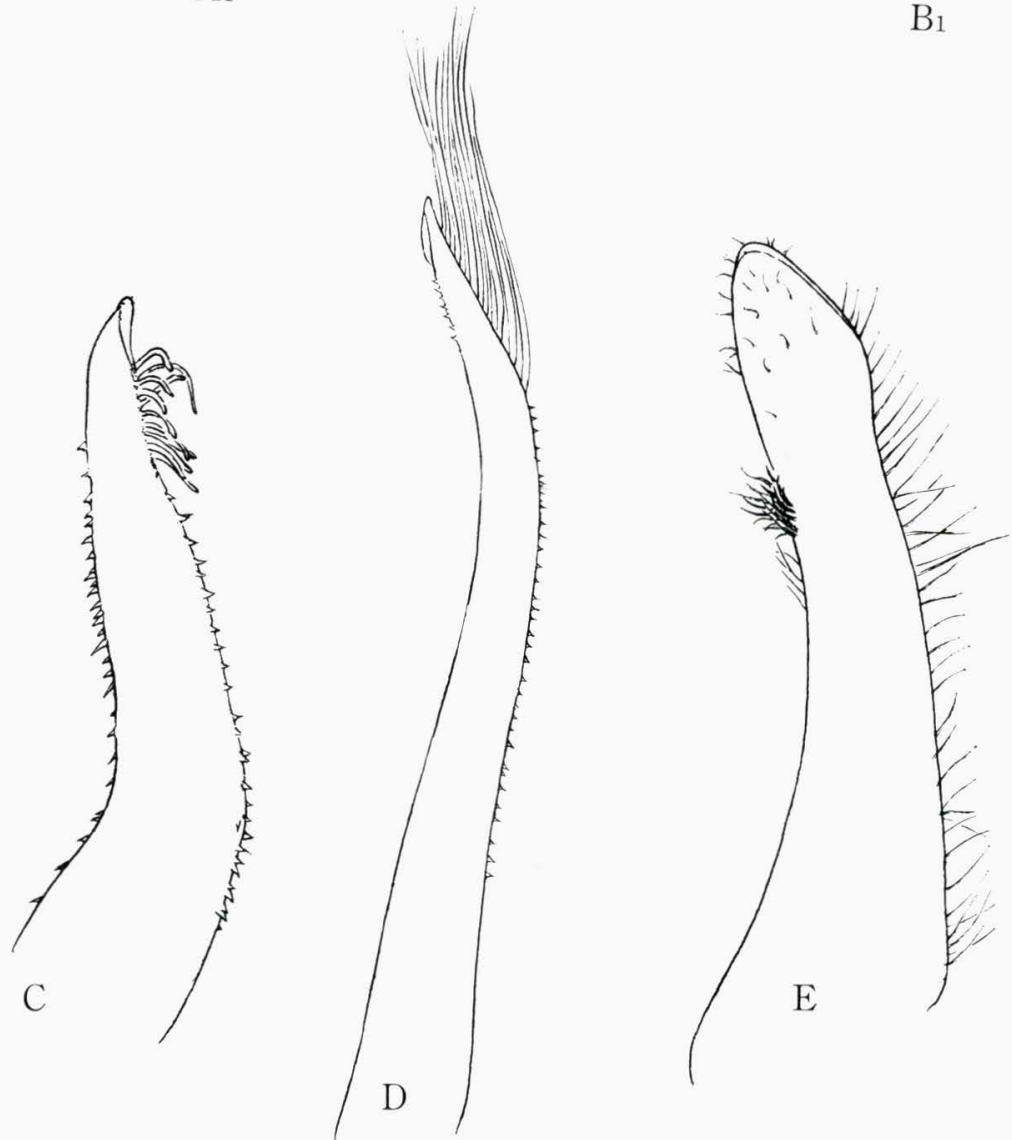


\section{Explanation of Plate VIII}
A. Cymonomus sagamiensis New Species. Carapace $\times 10$
B. Tip of anterior male pleopod of Lobiactaea lobipes, New Genus. $\times 75$
C. Tip of anterior male pleopod of Actumnus dorsipes STImpson. $\times 75$
D. Deiratonotus tondensis New Species. $\times 2.5$
$D_{1}$. Male abdomen of same. $\times 5$
$\mathrm{D}_{2 .}$. Anterior male pleopod of same. $\times 25$.
E. Eriocheir sinensis, mouth parts. $\times 4$
F. Neoeriocheir leptognathus (RAtнBL N, 1913). $\times 2.5$ 
Plate VIII
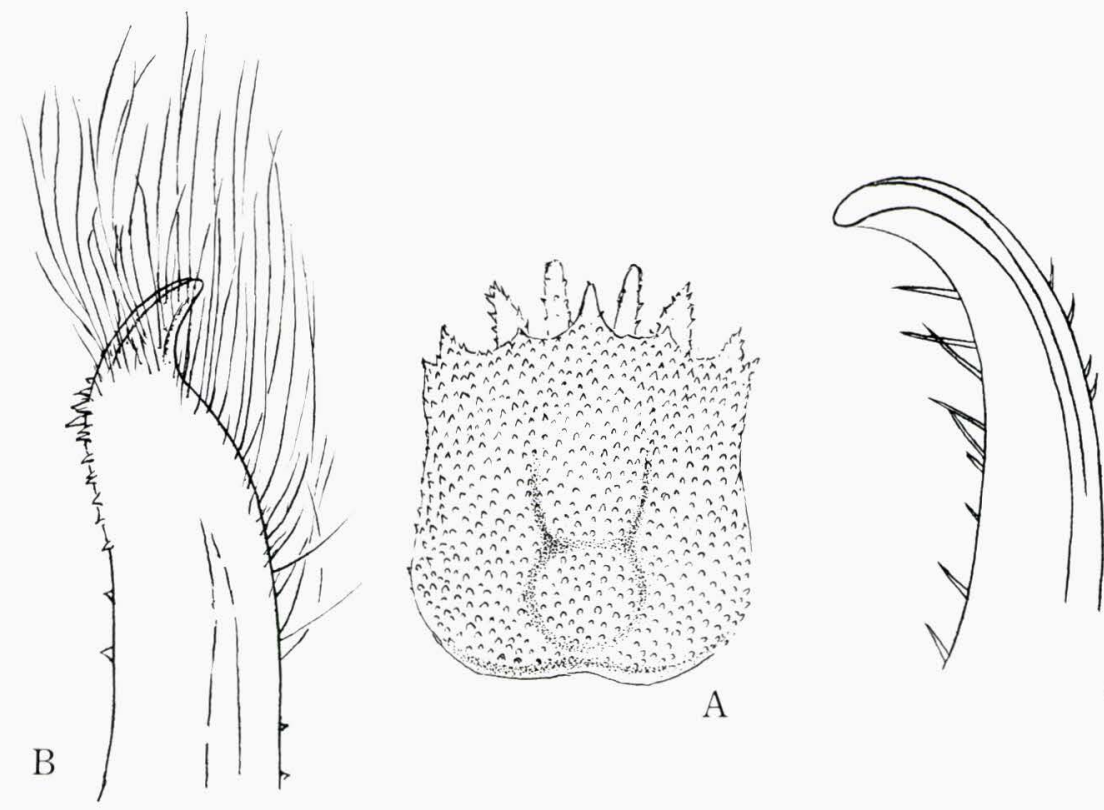

A

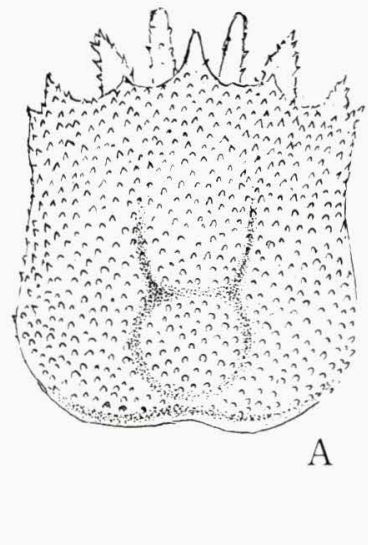

C
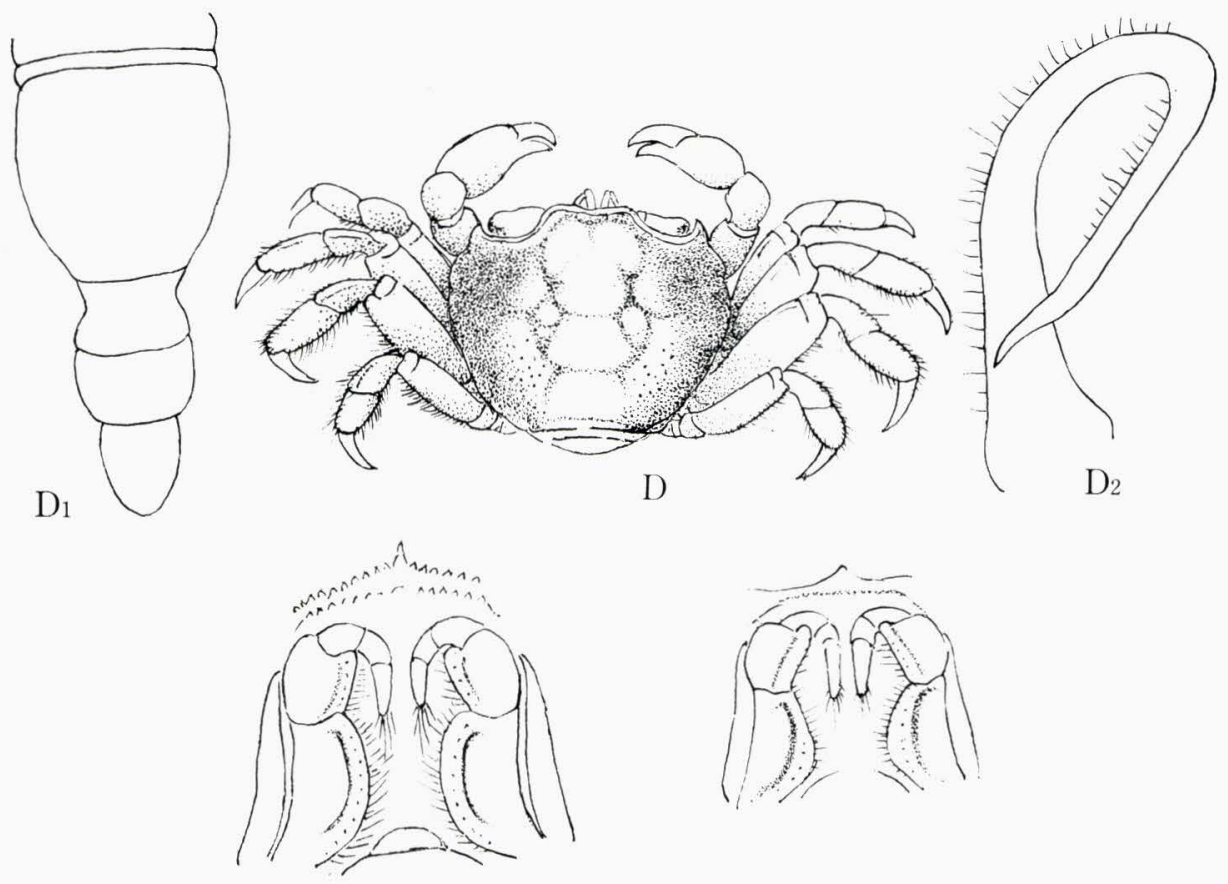

E

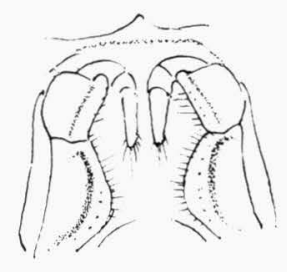

